\title{
N-Graphitic Modified Cobalt Nanoparticles Supported on Graphene for Tandem Dehydrogenation of Ammonia-Borane and Semihydrogenation of Alkynes
}

Garima Jaiswal, ${ }^{\text {a }}$ Vinod G. Landge, ${ }^{\text {ał }}$ Murugan Subaramanian, ${ }^{a}$ Ravishankar G. Kadam, ${ }^{\mathrm{b}}$ Radek Zbořil, ${ }^{\mathrm{b}}$ and Manoj B. Gawande, ${ }^{\mathrm{b}, \mathrm{c}}$ Ekambaram Balaraman ${ }^{\mathrm{a}^{*}}$

aDepartment of Chemistry, Indian Institute of Science Education and Research (IISER) Tirupati, Tirupati - 517507, India.

bRegional Centre of Advanced Technologies and Materials, Department of Physical Chemistry, Faculty of Science, Palacký University Olomouc, Šlechtitelů 27, 78371 Olomouc, Czech Republic.

'Institute of Chemical Technology Mumbai-Marathwada Campus, Jalna, Maharashtra 431203, India.

* Corresponding author: eb.raman@iisertirupati.ac.in

* Contributed equally.

Number of Pages: 48

Number of Figures: 33

Number of Tables: 2 


\section{Contents}

1. General Information $\quad$ S3

2. Experimental Section S4-S9

$\begin{array}{lr}\text { 3. Characterization of Catalyst } & \text { S10-S14 }\end{array}$

$\begin{array}{ll}\text { 4. Mechanistic Investigation } & \text { S15-S21 }\end{array}$

$\begin{array}{ll}\text { 5. Characterization Data } & \text { S22-S25 }\end{array}$

$\begin{array}{ll}\text { 6. References } & \text { S26 }\end{array}$

7. Literature report on cobalt-catalyzed hydrogenation of alkynes $\quad$ S27-S28

$\begin{array}{ll}\text { 8. Copy of Spectra } & \text { S29-S48 }\end{array}$ 


\section{General Information}

All catalytic experiments were carried out using standard Schlenk techniques. All solvents were reagent grade or better. Deuterated solvents were used as received without any additional purification. Most of the chemicals used in catalysis reactions were purified according to standard procedure (or by vacuum distillation/sublimation). ${ }^{1}$ Thin layer chromatography (TLC) was performed using silica gel precoated glass plates, which were visualized with visualized with UV light at $254 \mathrm{~nm}$ or under iodine. Column chromatography was performed with $\mathrm{SiO}_{2}$ (SilicycleSiliaflash F60 (230-400 mesh). ${ }^{1} \mathrm{H}$ NMR (400, 200 or $\left.500 \mathrm{MHz}\right),{ }^{13} \mathrm{C}\left\{{ }^{1} \mathrm{H}\right\}$ NMR $(100$ $\mathrm{MHz}$ ) spectra were recorded on the NMR spectrometer. Deuterated chloroform was used as the solvent, and chemical shift values $(\delta)$ are reported in parts per million relatives to the residual signals of this solvent $\left[\delta 7.27\right.$ for ${ }^{1} \mathrm{H}$ (chloroform-d), $\delta 77.0$ for ${ }^{13} \mathrm{C}\left\{{ }^{1} \mathrm{H}\right\}$ (chloroform-d). Abbreviations used in the NMR follow-up experiments: br, broad; s, singlet; d, doublet; t, triplet; q, quartet; m, multiplet. GC analysis was carried out using an HP-5 column (30 m, 0.25 $\mathrm{mm}, 0.25 \mu \mathrm{m})$. Mass spectra were obtained on a GCMS-QP 5000 instruments with ionization voltages of $70 \mathrm{eV}$. High-resolution mass spectra (HRMS) were obtained on a High-resolution mass spectra (HRMS) were obtained by fast atom bombardment (FAB) using a double focusing magnetic sector mass spectrometer and electron impact (EI) ionization technique (magnetic sector-electric sector double focusing mass analyzer). The modified Hummers method was followed to synthesize graphene oxide from graphite powder. ${ }^{2}$ Graphitic Oxide was heated at $160{ }^{\circ} \mathrm{C}$ for $12 \mathrm{~h}$ for exfoliation to get exfoliated graphene oxide (EGO). Other catalyst with different supports and ligands were synthesized in a similar way Co@NGR was synthesized in the main manuscript. 


\section{Experimental Section}

\subsection{Analytical methods}

Powder X-ray Diffraction: Powder X-ray diffraction of samples were analyzed on an X'Pert Pro model PANalytical diffractometer from PANalytical X'PERT PRO instruments operated at a voltage of $40 \mathrm{kV}$ and a current of $30 \mathrm{~mA}$ with $\mathrm{Cu}-K \alpha$ radiation $(\lambda=1.5406 \AA)$. The samples were scanned in a $2 \theta$ range from $10^{\circ}$ to $80^{\circ}$ with a scan rate of $0.39^{\circ}$ per minute as well by Co$\mathrm{K} \alpha$ radiation $(40 \mathrm{kV}, 30 \mathrm{~mA}, \lambda=0.1789 \mathrm{~nm})$ with a step size of $0.017^{\circ}$.

Transmission Electron Microscope: Samples suspended in ethanol were drop cast onto separate 200 mesh carbon coated copper grids and studied using a transmission electron microscope (TEM, FEI model TECNAI G2 F20) operating at an accelerating voltage of 200 $\mathrm{kV}$.

Energy Dispersive X-ray Analysis: Energy dispersive X-ray analysis (EDX) measurement on the active catalyst was performed using transmission electron microscope (TEM, FEI model TECNAI G2 F20) operating at an accelerating voltage of $200 \mathrm{kV}$.

Inductively Coupled Plasma Analysis: Inductively coupled plasma atomic emission spectroscopy (ICP-AES) were acquired for the elemental analysis of absolute iron content within the sample. Analysis performed by SPECTRO analytical instruments $\mathrm{GmbH}$, model ARCOS simultaneous ICP spectrometer, Germany.

Raman Analysis: LabRam spectrometer (HJY, France) was used for Raman analysis with a laser wavelength of $632 \mathrm{~nm}$.

X-ray Photoelectron Spectroscopy: XPS surface investigation has been performed on the PHI 5000 VersaProbe II XPS system (Physical Electronics) with a monochromatic Al-Ka source 
$(15 \mathrm{kV}, 50 \mathrm{~W})$ and photon energy of $1486.7 \mathrm{eV}$. Dual beam charge compensation was used for all measurements. All the spectra were measured in the vacuum of $1.3 \times 10^{-7} \mathrm{~Pa}$ and at the room temperature of $21{ }^{\circ} \mathrm{C}$. The analyzed area on each sample was a spot of $200 \mu \mathrm{m}$ in diameter. The survey spectra were measured with pass energy of $187.850 \mathrm{eV}$ and electronvolt step of $0.8 \mathrm{eV}$, while for the high-resolution spectra, pass energy of $23.500 \mathrm{eV}$ and electronvolt step of $0.2 \mathrm{eV}$ were used. The spectra were evaluated with the MultiPak (Ulvac - PHI, Inc.) software. All binding energy (BE) values were referenced to the carbon peak C 1s at 284.80 $\mathrm{eV}$.

Gas Chromatography Analysis: The conversion and selectivity of the reactions were analyzed by GC employing chromatograph Agilent 6820 (Agilent, United States), equipped with flame ionization detector (FID) and chromatographic column DB5 $(30 \times 0.250 \times 0.25)$. The following experimental parameters were applied: initial temperature of $100{ }^{\circ} \mathrm{C}$, increased to $250{ }^{\circ} \mathrm{C}$ with a rate of $10^{\circ} \mathrm{C} / \mathrm{min}$. 


\subsection{Catalyst Synthesis}

\section{2a Synthesis of N-doped nano-cobalt synthesis}

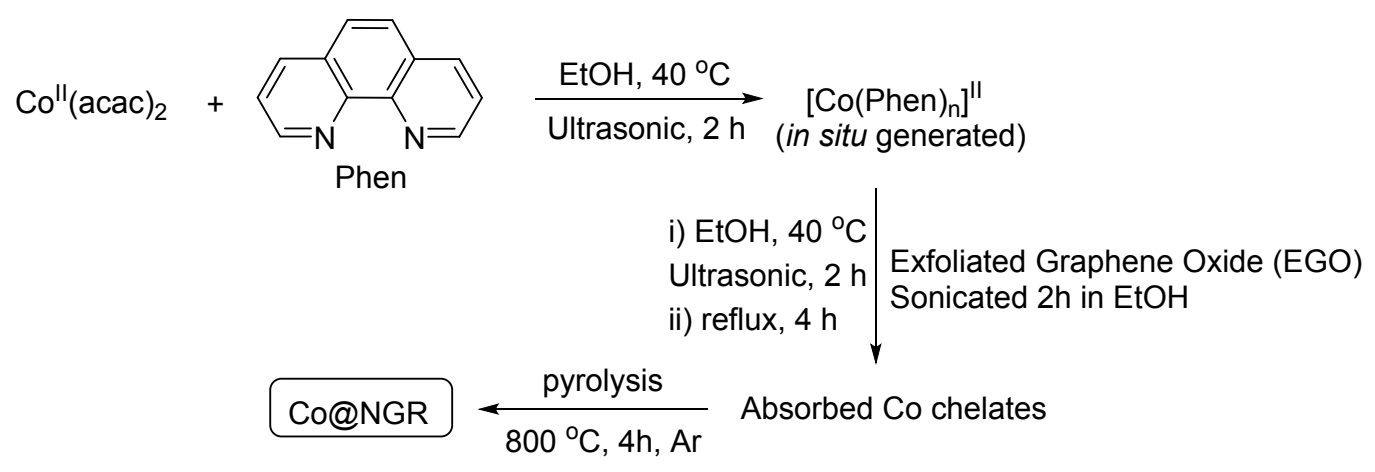

Scheme S1. Synthesis procedure of Co@NGR (nitrogen doped graphene) catalyst.

In a $100 \mathrm{~mL}$ beaker, cobalt(II) acetylacetonate precursor $(0.5 \mathrm{mmol})$ and 1,10-phenanthroline ligand (Phen; $0.5 \mathrm{mmol}$ ) were dissolved in $30 \mathrm{~mL}$ of ethanol and sonicated for $2 \mathrm{~h}$ to form Cophenanthroline complex. In another $250 \mathrm{~mL}$ beaker, $560 \mathrm{mg}$ of EGO (exfoliated graphene oxide) support was taken in $70 \mathrm{~mL}$ of ethanol and sonicated for $2 \mathrm{~h}$. The above obtained EGO suspension and the in situ generated Co-phenanthroline complex solution were mixed together in $250 \mathrm{~mL}$ beaker and further sonicated for $2 \mathrm{~h}$. The suspension was refluxed at $85{ }^{\circ} \mathrm{C}$ for $4 \mathrm{~h}$ and after cooling down to room temperature ethanol was evaporated in vacuum. The solid sample obtained was dried at $80{ }^{\circ} \mathrm{C}$ for $14 \mathrm{~h}$. Then, it was ground to a fine powder followed by heating at $800{ }^{\circ} \mathrm{C}$ under a stream of argon with the flow rate of $30 \mathrm{~mL} / \mathrm{min}$ and the heating rate: $25^{\circ} \mathrm{C} / \mathrm{min}$ for about $4 \mathrm{~h}$ to obtain a catalyst Co@NGR.

For the synthesis of other catalysts (Co-Bipy@G and Co-Py@G) was done using 0.5 mmol of the respective nitrogen ligands such as 2,2'-bipyridine and pyridine. Other steps in the synthesis were identical as per explained in the synthesis of Co@NGR. 


\section{2b Synthesis of $\mathrm{Co} @ \mathrm{SiO}_{2}, \mathrm{Co} @ \mathrm{TiO}_{2}$ and $\mathrm{Co} @ \mathrm{Al}_{2} \mathrm{O}_{3}$ catalysts:}

In a $100 \mathrm{~mL}$ beaker, cobalt(II) acetylacetonate precursor $(0.5 \mathrm{mmol})$ and 1,10-phenanthroline ligand (Phen; $0.5 \mathrm{mmol}$ ) were dissolved in $30 \mathrm{~mL}$ of ethanol and sonicated for $2 \mathrm{~h}$ to form Cophenanthroline complex. In another $250 \mathrm{~mL}$ beaker, $560 \mathrm{mg}$ of the respective support $\left(\mathrm{SiO}_{2}\right.$ support for $\mathrm{Co} @ \mathrm{SiO}_{2}$ synthesis, $\mathrm{TiO}_{2}$ support for $\mathrm{Co} @ \mathrm{TiO}_{2}$ synthesis, and $\mathrm{Al}_{2} \mathrm{O}_{3}$ support for $\mathrm{Co} @ \mathrm{Al}_{2} \mathrm{O}_{3}$ synthesis) was taken in $70 \mathrm{~mL}$ of ethanol and sonicated for $2 \mathrm{~h}$. The suspension of support in ethanol and the in situ generated Co-phenanthroline complex solution were mixed together in $250 \mathrm{~mL}$ beaker and further sonicated for $2 \mathrm{~h}$. The suspension was refluxed at $85^{\circ} \mathrm{C}$ for $4 \mathrm{~h}$ and after cooling down to room temperature ethanol was evaporated in vacuum. The solid sample obtained was dried at $80{ }^{\circ} \mathrm{C}$ for $14 \mathrm{~h}$. Then, it was ground to a fine powder followed by heating at $800{ }^{\circ} \mathrm{C}$ under a stream of argon with the flow rate of $30 \mathrm{~mL} / \mathrm{min}$ and the heating rate: $25{ }^{\circ} \mathrm{C} / \mathrm{min}$ for about $4 \mathrm{~h}$ to obtain the respective supported catalysts $\left(\mathrm{Co} @ \mathrm{SiO}_{2}\right.$, $\mathrm{Co} @ \mathrm{TiO}_{2}$ and $\mathrm{Co} @ \mathrm{Al}_{2} \mathrm{O}_{3}$ catalysts).

\section{2c Synthesis of Phen@GR}

In a $50 \mathrm{~mL}$ beaker, $90 \mathrm{mg}$ of 1,10-phenanthroline was dissolved in $10 \mathrm{~mL}$ of ethanol. In another $250 \mathrm{~mL}$ beaker, $560 \mathrm{mg}$ of EGO (exfoliated graphene oxide) support was taken in 70 $\mathrm{mL}$ of ethanol and sonicated for $2 \mathrm{~h}$. The above obtained EGO suspension, and the 1,10phenanthroline in ethanol were mixed together in $250 \mathrm{~mL}$ beaker and further sonicated for $2 \mathrm{~h}$. The suspension was refluxed at $85{ }^{\circ} \mathrm{C}$ for $4 \mathrm{~h}$ and after cooling down to room temperature ethanol was evaporated in vacuum. The solid sample obtained was dried at $80{ }^{\circ} \mathrm{C}$ for $14 \mathrm{~h}$. 
Then, it was ground to a fine powder followed by heating at $800{ }^{\circ} \mathrm{C}$ under a stream of argon with the flow rate of $30 \mathrm{~mL} / \mathrm{min}$ and the heating rate: $25{ }^{\circ} \mathrm{C} / \mathrm{min}$ for about $4 \mathrm{~h}$ to obtain Phen@GR catalyst.

\section{2d Synthesis of Co@GR}

In a $50 \mathrm{~mL}$ beaker, $26 \mathrm{mg}$ of cobalt(II) acetylacetonate was dissolved in $10 \mathrm{~mL}$ of ethanol. In another $250 \mathrm{~mL}$ beaker, $560 \mathrm{mg}$ of EGO (exfoliated graphene oxide) support was taken in 70 $\mathrm{mL}$ of ethanol and sonicated for $2 \mathrm{~h}$. The above obtained EGO suspension, and the cobalt(II) acetylacetonate in ethanol were mixed together in $250 \mathrm{~mL}$ beaker and further sonicated for $2 \mathrm{~h}$. The suspension was refluxed at $85{ }^{\circ} \mathrm{C}$ for $4 \mathrm{~h}$ and after cooling down to room temperature ethanol was evaporated in vacuum. The solid sample obtained was dried at $80{ }^{\circ} \mathrm{C}$ for $14 \mathrm{~h}$. Then, it was ground to a fine powder followed by heating at $800{ }^{\circ} \mathrm{C}$ under a stream of argon with the flow rate of $30 \mathrm{~mL} / \mathrm{min}$ and the heating rate: $25^{\circ} \mathrm{C} / \mathrm{min}$ for about $4 \mathrm{~h}$ to obtain Co@GR catalyst.

\subsection{General Procedure for Z-Selective Semi-Hydrogenation of Internal Alkynes}

To an oven-dried $10 \mathrm{~mL}$ screw-capped vial, alkyne $\mathbf{1}(0.5 \mathrm{mmol})$, ammonia-borane ( $0.6 \mathrm{mmol})$, Co@NGR catalyst (4 mol\%), and methanol $(2 \mathrm{~mL})$ were added under a gentle stream of argon. The reaction mixture was stirred for $24 \mathrm{~h}$ at $80{ }^{\circ} \mathrm{C}$. The reaction mixture was filtered through a short pad of Celite and the solvent was removed in vacuo. The yield of alkene was determined by gas chromatography. 


\subsection{General Procedure for Semi-Hydrogenation of Terminal Alkynes}

To an oven-dried $10 \mathrm{~mL}$ screw-capped vial, terminal alkyne 4 (0.5 mmol), ammonia-borane (0.6 mmol), Co@NGR catalyst (4 mol\%), and methanol (2 mL) were added under a gentle stream of argon. The reaction mixture was stirred for $18 \mathrm{~h}$ at $80{ }^{\circ} \mathrm{C}$. The reaction mixture was filtered through a short pad of Celite and the solvent was removed in vacuo. The yield of alkene was determined by gas chromatography.

Precaution: The transfer semi-hydrogenation reaction should be performed using heavy-wall borosilicate glass vial under fuming cupboard and the temperature of the reaction should be maintained $\left(80{ }^{\circ} \mathrm{C}\right)$. Before opening the glass vial, the reaction vial was cooled down to $0{ }^{\circ} \mathrm{C}$ and slowly vented the excess hydrogen gas (if any). 


\section{Characterization of Catalyst}

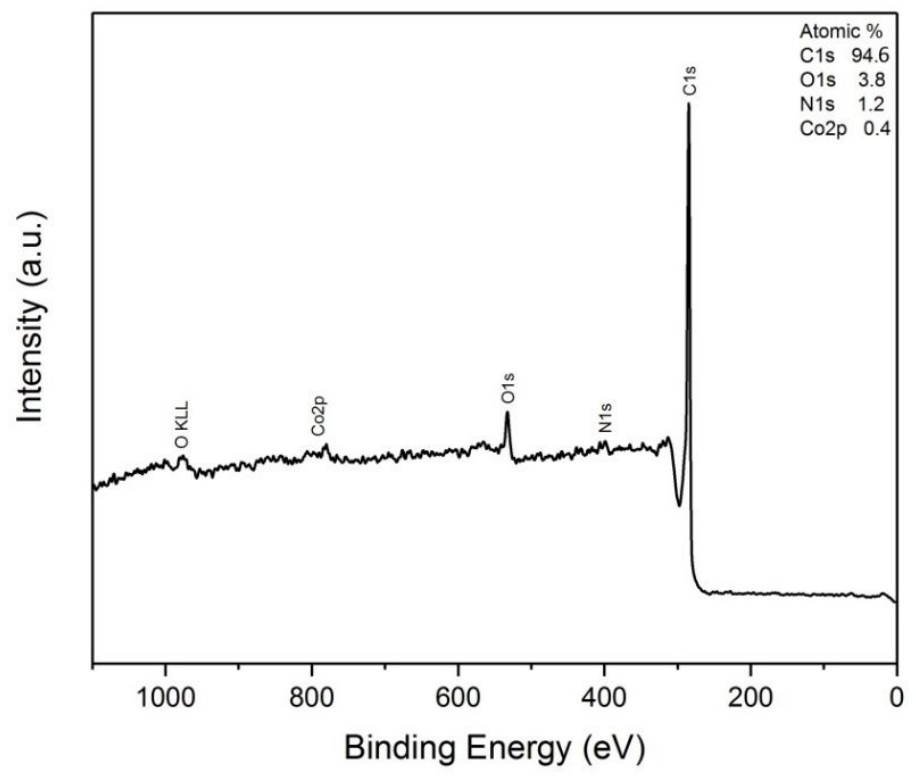

Figure S1. XPS survey spectra of the Co@NGR catalyst.

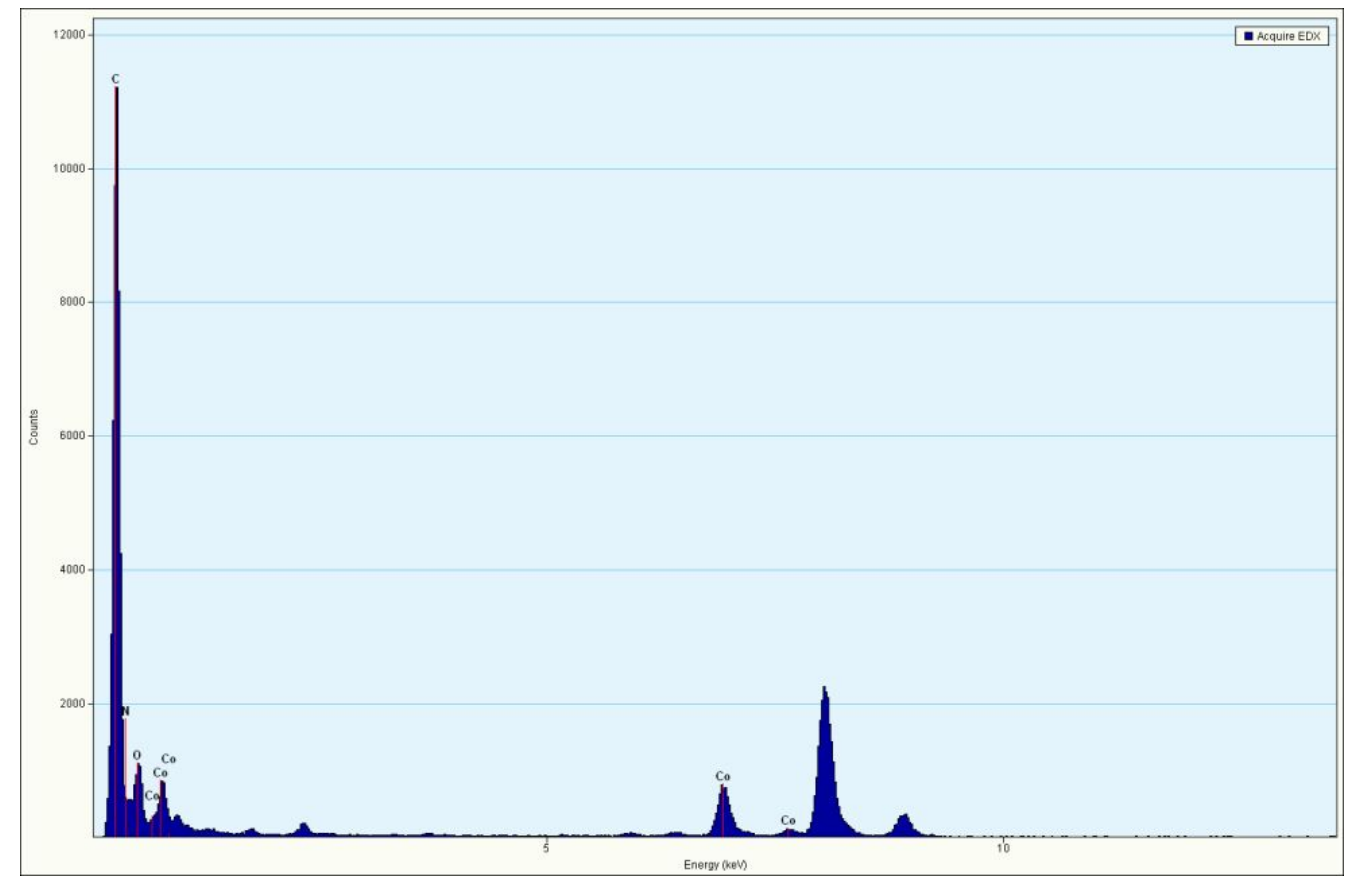

Figure S2. EDX analysis of Co@NGR catalyst. 
Table S1. Weight percent of different elements in the Co@NGR catalyst.

\begin{tabular}{cccccc}
\hline Element & Weight \% & Atomic \% & Uncert. \% & Correction & k-Factor \\
\hline $\mathrm{C}(\mathrm{K})$ & 86.52 & 91.41 & 0.41 & 0.26 & 3.940 \\
$\mathrm{~N}(\mathrm{~K})$ & 4.79 & 4.34 & 0.12 & 0.26 & 3.826 \\
$\mathrm{O}(\mathrm{K})$ & 4.10 & 3.25 & 0.07 & 0.49 & 1.974 \\
$\mathrm{Co}(\mathrm{K})$ & 4.57 & 0.98 & 0.05 & 0.99 & 1.403
\end{tabular}
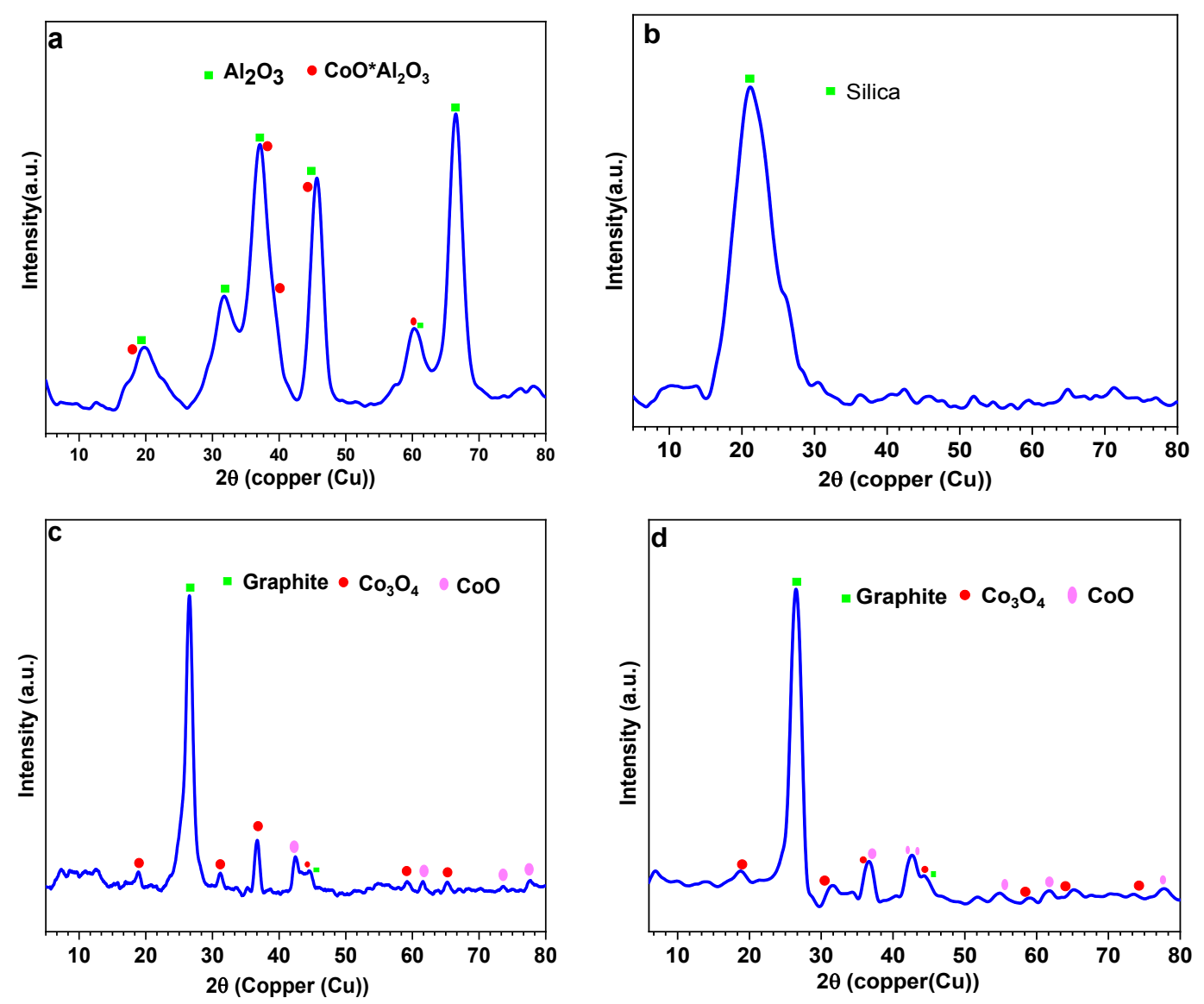

Figure S3. PXRD of (a) $\mathrm{Co} @ \mathrm{Al}_{2} \mathrm{O}_{3}$, (b) $\mathrm{Co} @ \mathrm{SiO}_{2}$, (c) Co-Bipy@G and (d) Co-Py@G 
Sample $\mathrm{Co} @ \mathrm{Al}_{2} \mathrm{O}_{3}$ demonstrated the peaks at $19.3^{\circ}, 31.8^{\circ}, 37.5^{\circ}, 45.6^{\circ}, 60.5^{\circ}$ and $66.5^{\circ}$ correspond to $\mathrm{Al}_{2} \mathrm{O}_{3}$ (Reference Code: 96-201-5531). Peaks at $19.2^{\circ}, 37.3^{\circ}, 39.0^{\circ}, 45.4^{\circ}$ and $60.0^{\circ}$ are assined to a defect spinel $\mathrm{CoO}^{*} 3 \mathrm{Al}_{2} \mathrm{O}_{3}$, constituting cobalt (Reference Code: 96-1545122) (Fig S3-a). Sample Co@silica showed only the silica phase (Fig S3-a). The sample preapred by using Bypyridyl as ligand (Co-Bipy@G) showed the peaks at $26.5^{\circ}$ and $44.5^{\circ}$ that belongs to graphitc phase (Referance code :96-901-2231), and peaks positioned at $18.9^{\circ}, 31.2^{\circ}$, $36.7^{\circ}, 44.7^{\circ}, 59.2^{\circ}$ and $65.1^{\circ}$ are assinged to $\mathrm{Co}_{3} \mathrm{O}_{4}$ phase (Reference Code: 96-900-5889), and the peaks positioned at $36.4^{\circ}, 42.3^{\circ}, 61.4^{\circ}, 73.6^{\circ}, 77.5^{\circ}$ and $65.1^{\circ}$ are assinged to $\mathrm{CoO}$ phase (Reference Code: 96-153-3088), respectively (Fig S3-c). The sample prepared by using pyridine as ligand (Co-Py@G) was analysed carefully. In XRD, peaks potioned at $26.5^{\circ}$ and $44.5^{\circ}$ confirmed the graphite phase (Reference Code: 96-901-2231), and peakts at $36.6^{\circ}, 42.3^{\circ}$, $42.8^{\circ}, 61.8^{\circ}$ and $77.8^{\circ}$ are assinged to $\mathrm{CoO}$ (Reference Code: $96-152-8839$ ). Peaks postoined at $18.7^{\circ}, 30.9^{\circ}, 36.7^{\circ}, 44.2^{\circ}, 58.6^{\circ}$ and $64.4^{\circ}$ revealed the presence of $\mathrm{Co}_{3} \mathrm{O}_{4}$ phase (Reference Code: 96- 900-5894) (Fig S3-d).
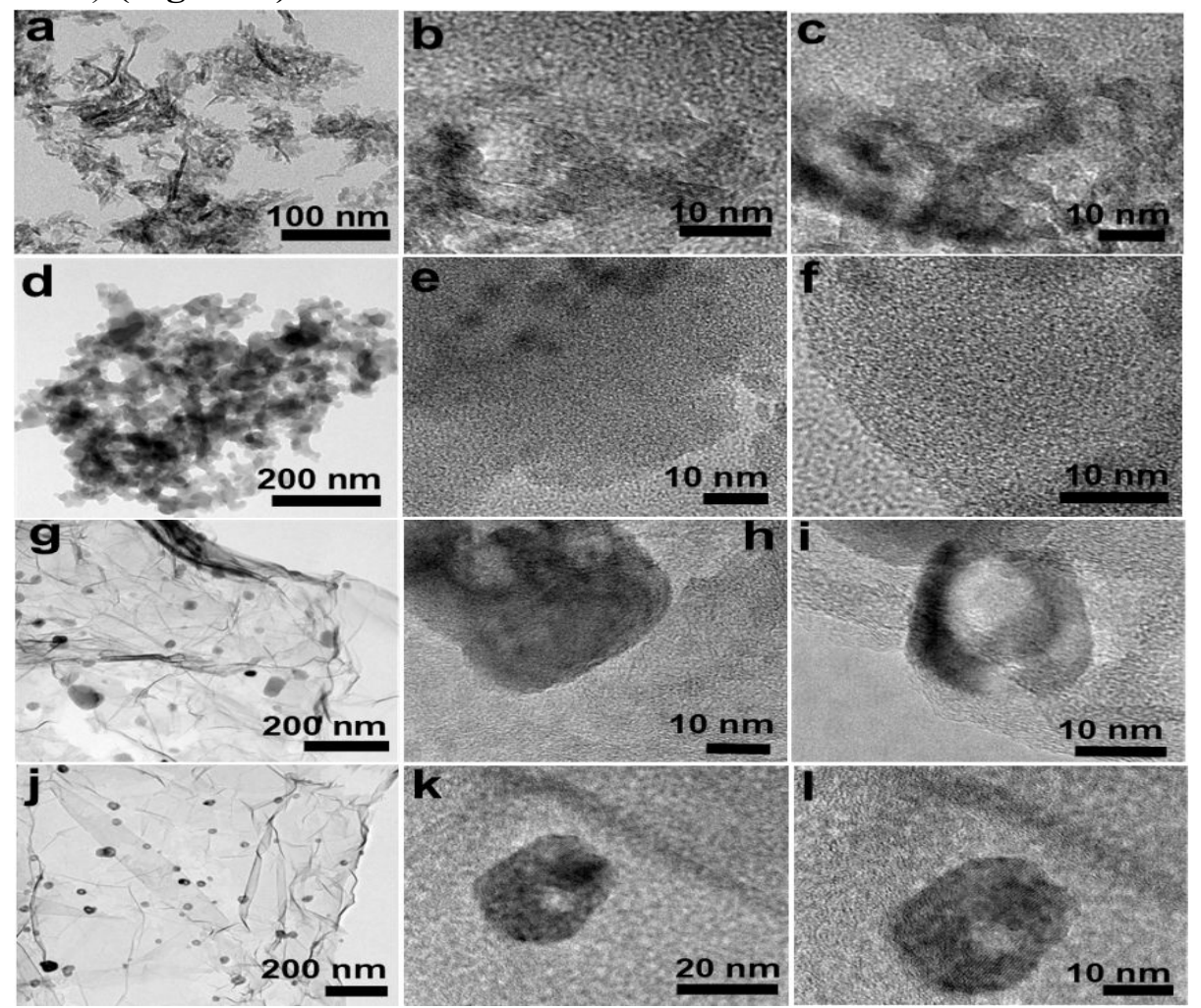

Figure S4. TEM and HRTEM images for samples image of $\mathrm{Co} @ \mathrm{Al}_{2} \mathrm{O}_{3}(\mathrm{a}-\mathrm{c}), \mathrm{Co} @ \mathrm{SiO}_{2}(\mathrm{~d}-\mathrm{f})$, Co-Bpy@G (g-i), and Co-Py@G (j-1). 


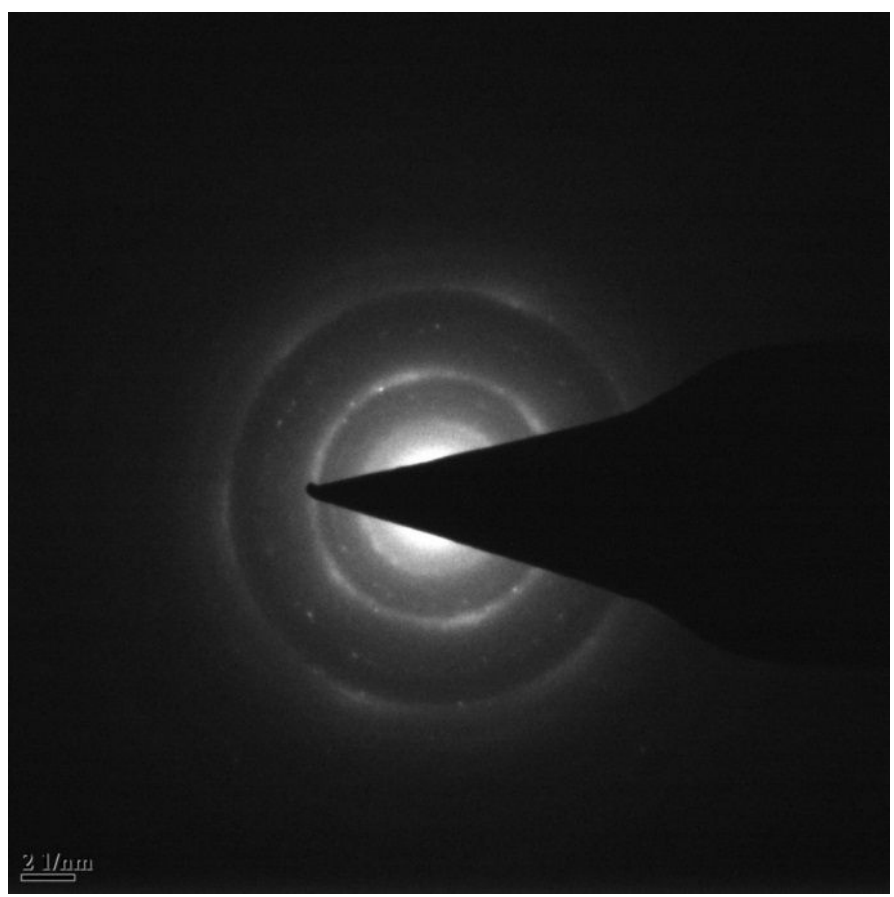

Figure S5. SAED pattern Co@NGR catalyst.

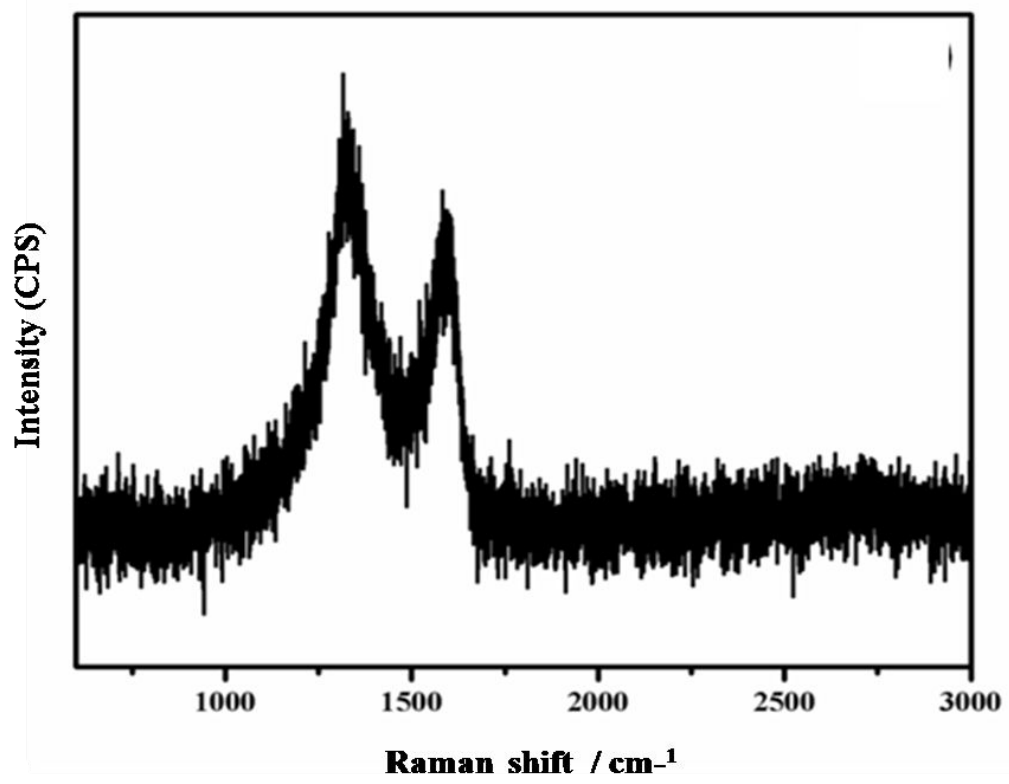

Figure S6. Raman spectra Co@NGR catalyst. 


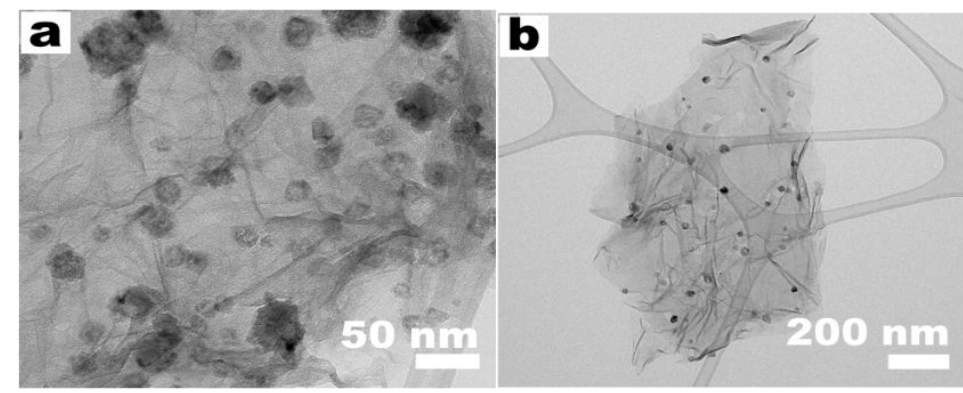

Figure S7. TEM image of reused Co@NGR catalyst (a) at $50 \mathrm{~nm}$ scale and (b) $200 \mathrm{~nm}$ scale.

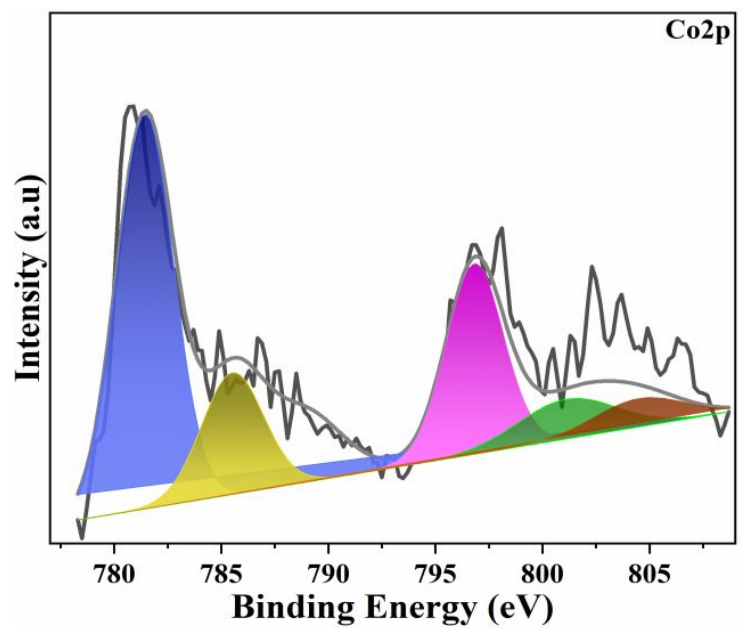

Figure S8. XPS spectra of reused Co@NGR catalyst Co2p region.

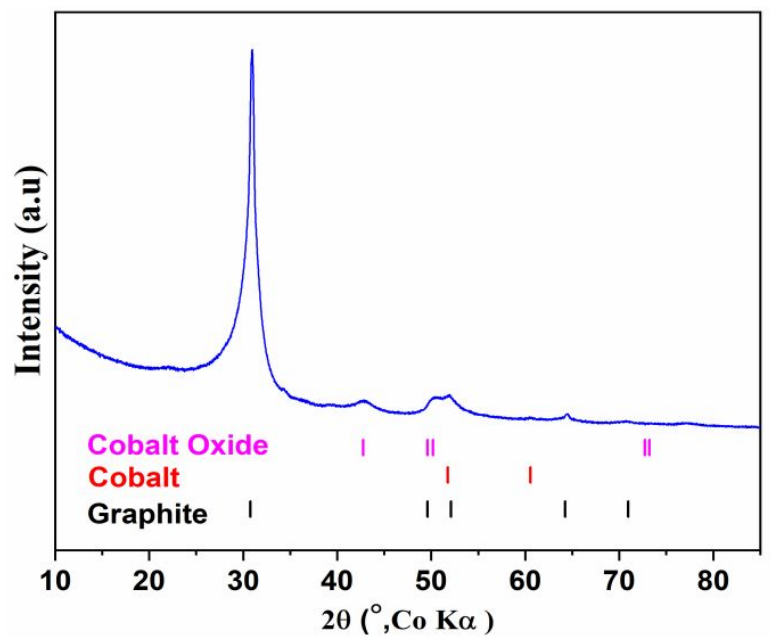

Figure S9. Powder X-ray diffraction (PXRD) profile for reused Co@NGR catalyst. 


\section{Mechanistic Investigation}

\section{1. $\mathbf{H}_{2}$ Detection}

To an oven-dried $10 \mathrm{~mL}$ screw-capped vial, alkyne $\mathbf{1 b}(0.1 \mathrm{mmol})$, ammonia-borane $(0.15$ mmol), Co@NGR catalyst (4 mol\%) and methanol ( $2 \mathrm{~mL})$ were added under a gentle stream of argon. The reaction mixture was stirred for $24 \mathrm{~h}$ at $80^{\circ} \mathrm{C}$. After $6 \mathrm{~h}$, the gas was also collected by a gas-tight syringe and qualitatively analyzed by GC-TCD with a Carbon plot capillary column gas chromatography which showed the presence of $\mathrm{H}_{2}$ gas at retention time $1.27 \mathrm{~min}$. The retention time of hydrogen gas is already calibrated (1.28 min).

GC Conditions:

GC make \& Column: Agilent 7890 GC carbosphere column; Detector: Thermal Conductivity Detector (TCD); Carrier gas: Nitrogen; Make up flow of $\mathrm{N}_{2}: 5 \mathrm{~mL} / \mathrm{min}$; Detector Temperature: 200 degree Celsius and oven temperature 80 degree Celsius at the time of injection.
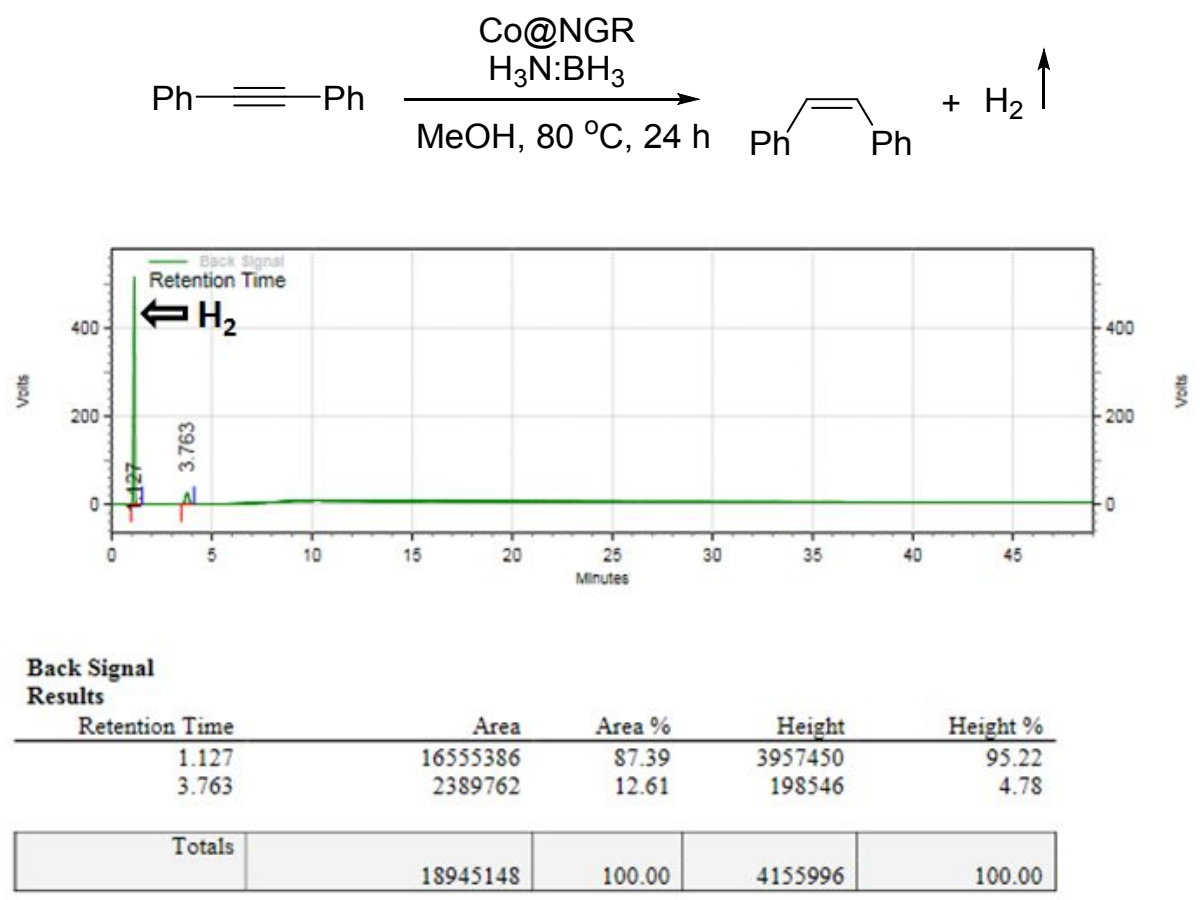

Figure S10. GC data of gaseous sample. 


\subsection{Labelling Experiment}

To an oven-dried $10 \mathrm{~mL}$ screw-capped vial, alkyne $\mathbf{1 b}(0.1 \mathrm{mmol})$, ammonia-borane $(0.15$ mmol), Co@NGR catalyst (4 mol\%) and $\mathrm{CD}_{3} \mathrm{OD}(2 \mathrm{~mL})$ were added under a gentle stream of argon. The reaction mixture was stirred for $24 \mathrm{~h}$ at $80^{\circ} \mathrm{C}$. The reaction mixture was filtered through a short pad of Celite and the solvent was removed in vacuo. The residue was purified by column chromatography on silica gel (eluent: pet ether) to afford the desired product [D]-2b (90\% yield).
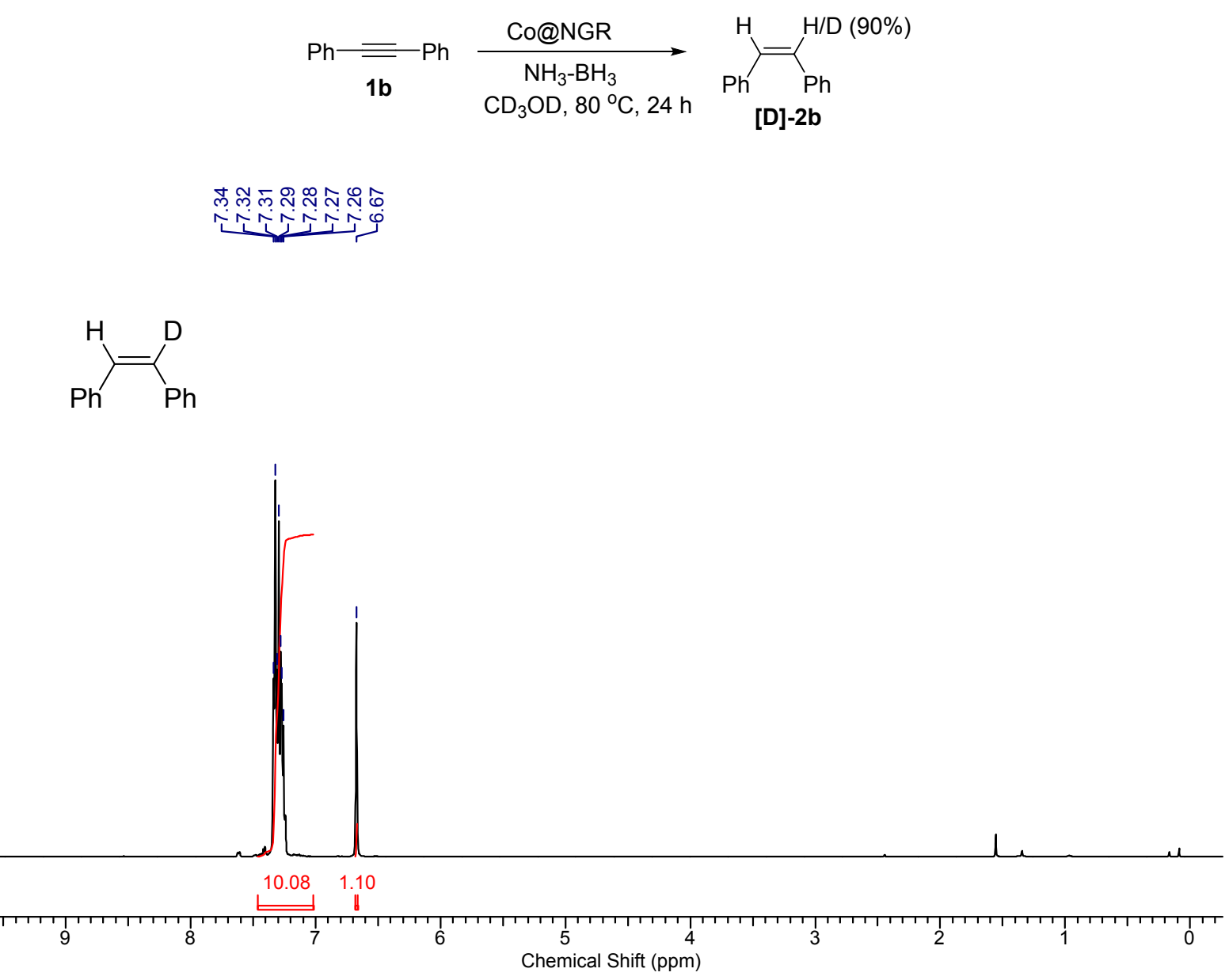

Figure S11. ${ }^{1} \mathrm{H}$ NMR of [D]-2a. 


\subsection{Determination of the Dehydrogenation Product of Ammonia-Borane}

To an oven-dried $10 \mathrm{~mL}$ screw-capped vial, alkyne 1a $(0.1 \mathrm{mmol})$, ammonia-borane $(0.15$ mmol),Co@NGR catalyst (4 mol\%) and methanol (2 mL) were added under a gentle stream of argon. The reaction mixture was stirred for $24 \mathrm{~h}$ at $80{ }^{\circ} \mathrm{C}$. After cooling to room temperature, the reaction mixture was filtered through a short pad of Celite and recorded ${ }^{11} \mathrm{~B}$ NMR (External reference: $\mathrm{BF}_{3} \cdot \mathrm{OEt}_{2}$, Solvent D-THF). The ${ }^{11} \mathrm{~B}$ NMR showed that a complete conversion of $\mathrm{AB}$ into $\mathrm{B}(\mathrm{OMe})_{3}$ (also confirmed by GC-MS) and other B-N bonded compounds. The formation of dihydrogen was detected on GC.

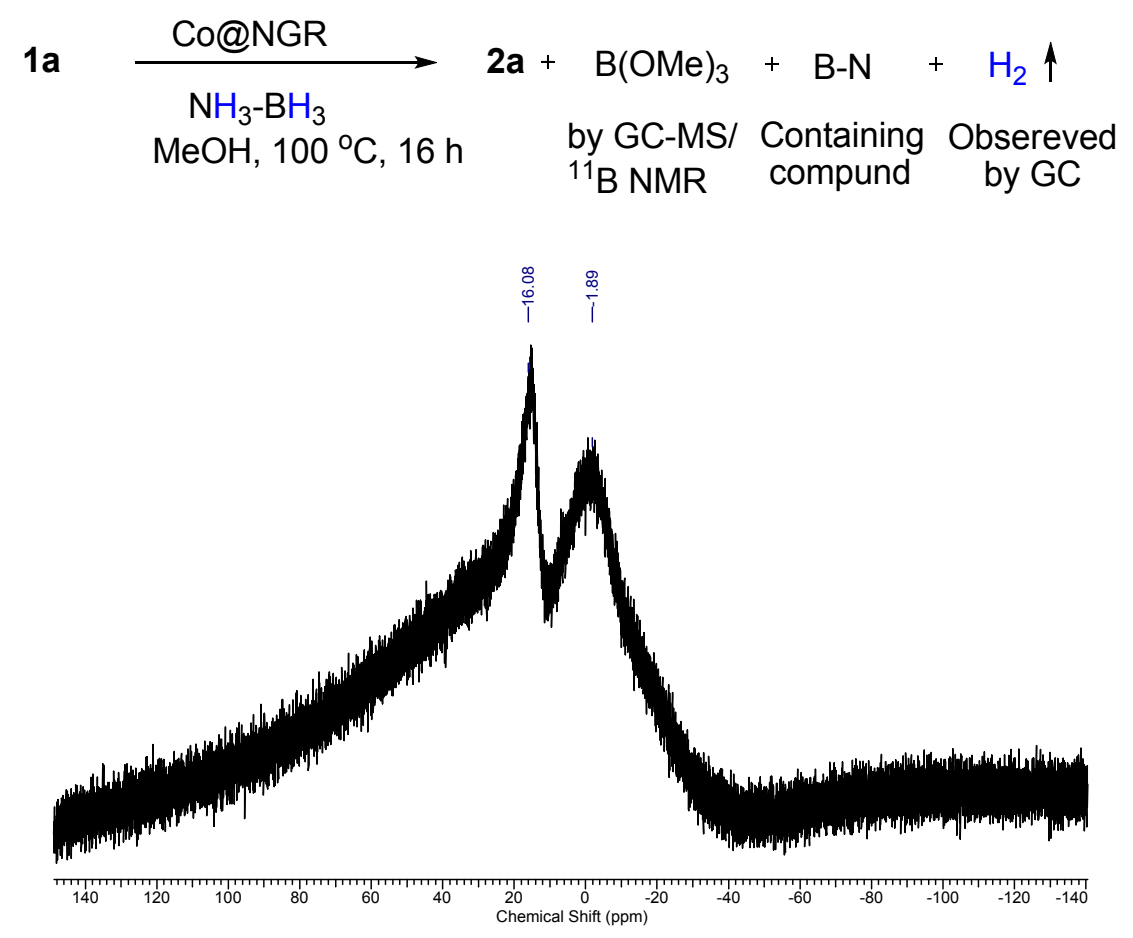

Figure S12. ${ }^{11}$ B NMR of crude reaction mixture. 


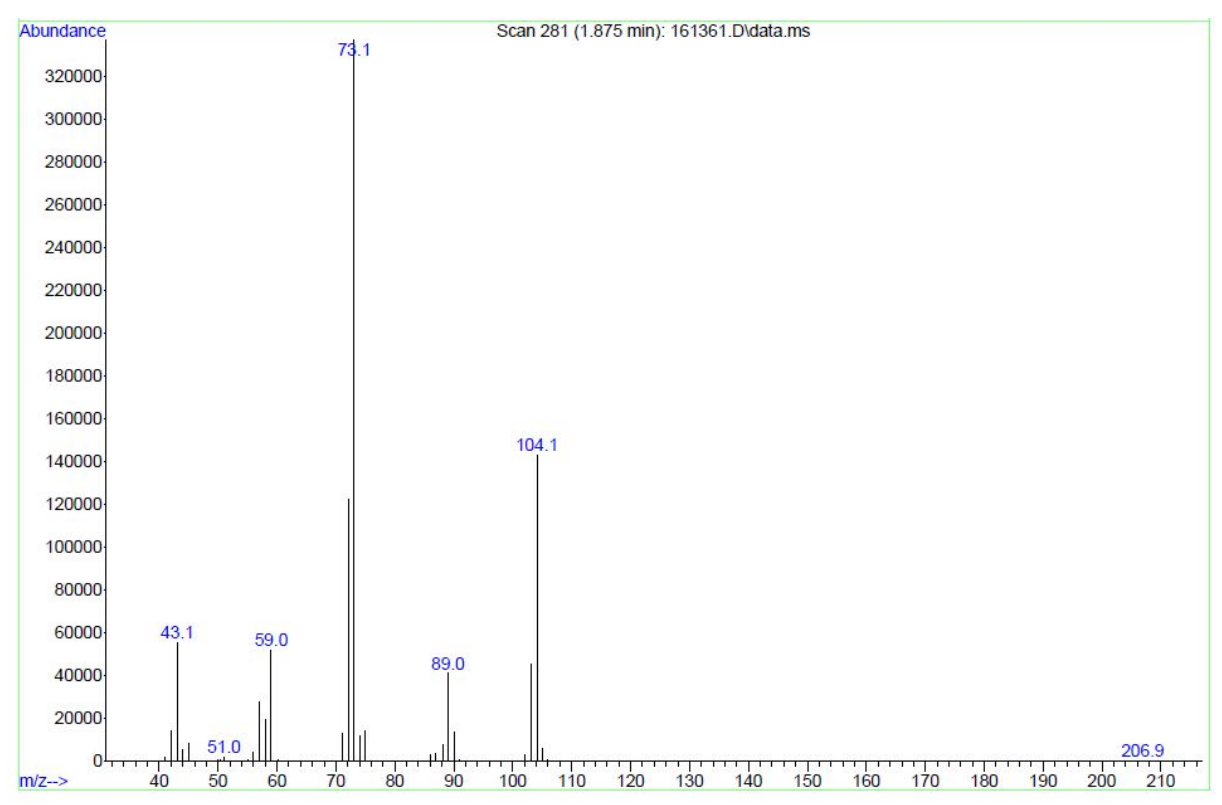

Figure S13. GC-MS of crude reaction mixture.

\subsection{Reaction Profile for the Cobalt-Catalyzed Transfer Hydrogenation of $1 \mathrm{~b}$}

To an oven-dried $10 \mathrm{~mL}$ screw-capped vial, all eleven parallel reaction kept using $\mathbf{1 d}(0.1$ mmol), ammonia-borane (0.2 mmol), Co@NGR catalyst (4 mol\%), n-decane (0.1 mmol), and $\mathrm{MeOH}(2 \mathrm{~mL})$ were added under a gentle stream of argon. The reaction mixture was stirred at $80{ }^{\circ} \mathrm{C}$. At regular time intervals, the reaction mixture was analyzed on GC.

\subsection{Competitive Experiment (Alkyne vs. Alkene)}

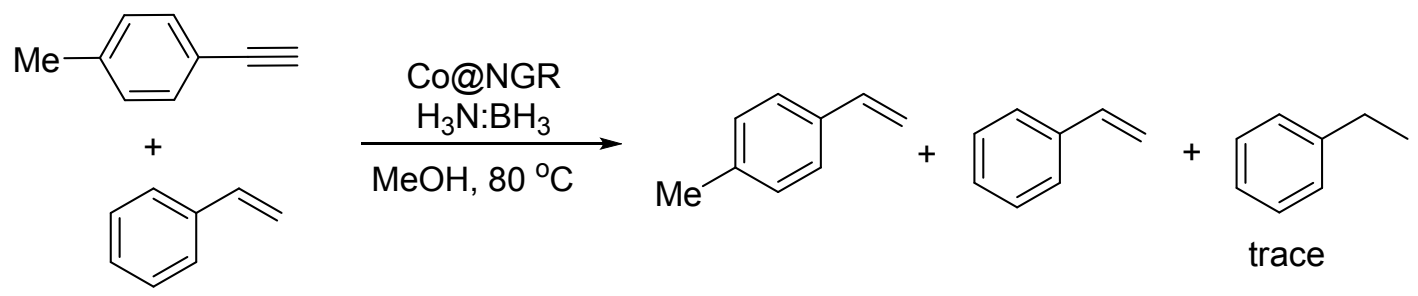

To an oven-dried $10 \mathrm{~mL}$ screw-capped vial, all eleven parallel reaction kept using 4-methyl phenyl acetylene $(0.1 \mathrm{mmol}), \mathrm{Co} @ N G R$ catalyst $(4 \mathrm{~mol} \%)$, styrene $(0.1 \mathrm{mmol})$, ammonia- 
borane $(0.2 \mathrm{mmol}), \mathrm{n}$-decane $(0.1 \mathrm{mmol})$, and $\mathrm{MeOH}(2 \mathrm{~mL})$ were added under a gentle stream of argon. The reaction mixture was stirred at $80{ }^{\circ} \mathrm{C}$. At regular time intervals, the reaction mixture was analyzed on GC.

\subsection{Isomerisation Experiment}

\section{(a) In presence of ammonia-borane (AB)}

To an oven-dried $10 \mathrm{~mL}$ screw-capped vial, $\mathbf{2 b}$ or $\mathbf{3 b}(0.1 \mathrm{mmol})$, ammonia-borane $(0.15$ mmol), Co@NGR catalyst (4 mol\%) and methanol ( $2 \mathrm{~mL})$ were added under a gentle stream of argon. The reaction mixture was stirred for $24 \mathrm{~h}$ at $80{ }^{\circ} \mathrm{C}$. After cooling to room temperature, the reaction mixture was filtered through a short pad of Celite and the solvent was removed in vacuo. The yield of alkene was determined by gas chromatography.

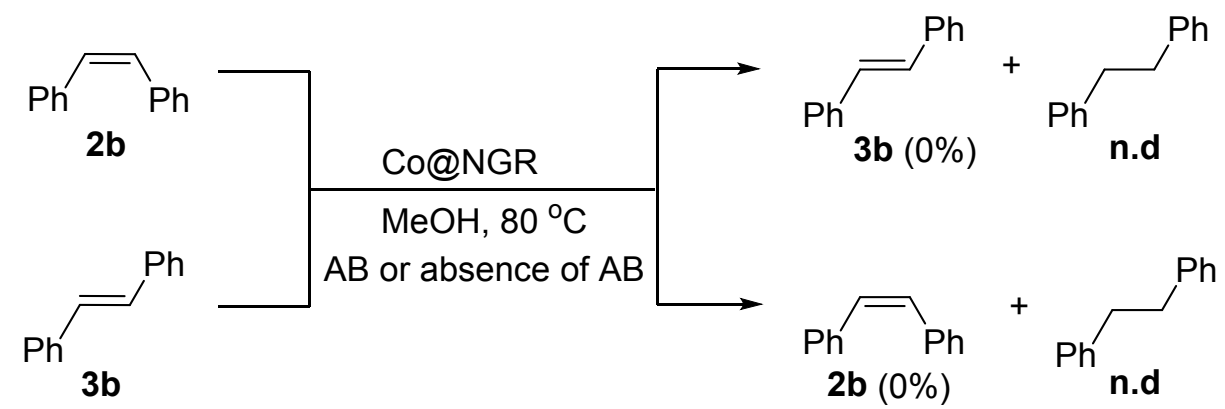

\section{(b) In absence of ammonia-borane (AB)}

To an oven-dried $10 \mathrm{~mL}$ screw-capped vial, 2b or 3b $(0.1 \mathrm{mmol})$, Co@NGR catalyst (4 mol\%) and methanol $(2 \mathrm{~mL})$ were added under a gentle stream of argon. The reaction mixture was stirred for $24 \mathrm{~h}$ at $80^{\circ} \mathrm{C}$. After cooling to room temperature, the reaction mixture was filtered through a short pad of Celite and the solvent was removed in vacuo. The yield of alkene was determined by gas chromatography. 


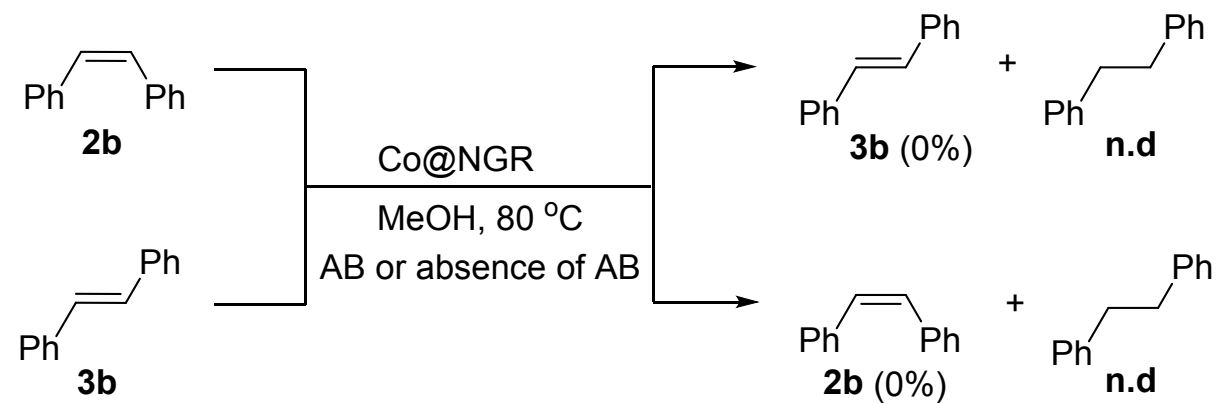

\subsection{Selective Hydrogenation of Alkyne over Alkene}

To an oven-dried $10 \mathrm{~mL}$ screw-capped vial, phenylacetylene $(0.1 \mathrm{mmol}), \mathbf{2 b}(0.1 \mathrm{mmol}), \mathbf{3 b}$ (0.1 mmol), ammonia-borane (0.15 mmol), Co@NGR catalyst (4 mol\%) and methanol (2 mL) were added under a gentle stream of argon. The reaction mixture was stirred for $24 \mathrm{~h}$ at $80{ }^{\circ} \mathrm{C}$. After cooling to room temperature, the reaction mixture was filtered through a short pad of Celite and the solvent was removed in vacuo. The yield of the products was determined by gas chromatography which showed that only phenyl acetylene underwent hydrogenation.

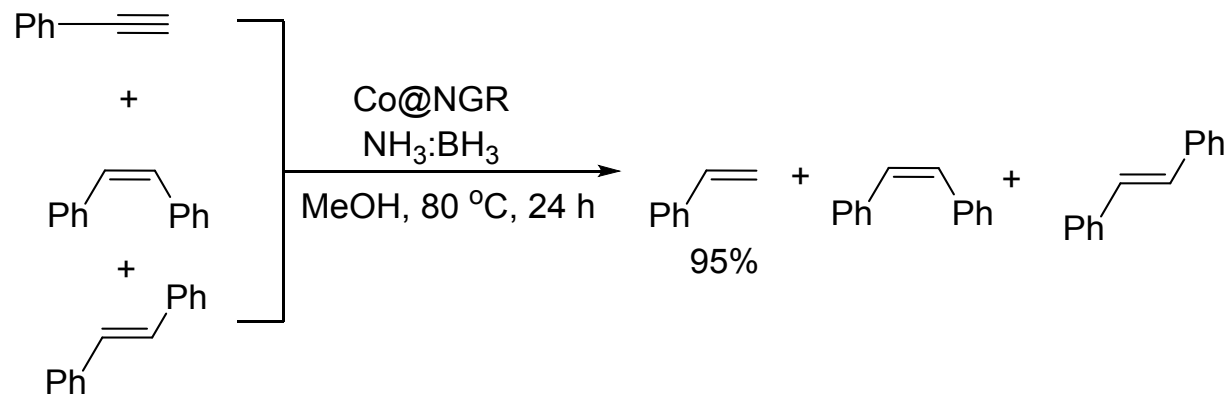

\subsection{Recyclability of the Catalyst}

To an oven dried capped sealed tube $(15 \mathrm{~mL})$, Co@NGR catalyst $(4 \mathrm{~mol} \%)$, alkyne $(0.25$ $\mathrm{mmol})$, aminoborane $(0.5 \mathrm{mmol})$ and methanol $(2 \mathrm{~mL})$ were added under argon atmosphere. The reaction mixture was heated at $80{ }^{\circ} \mathrm{C}$ with stirring. After cooling the reaction mixture to room temperature, the catalyst was separated from the reaction mixture by centrifugation method and the filtered catalyst was washed with methanol $(4 \times 2 \mathrm{~mL})$. Then, the catalyst was 
dried under vacuum at $80^{\circ} \mathrm{C}$ for $12 \mathrm{~h}$ and reused for the next cycle. It was observed that there is no deactivation of the catalytic material up to nine cycles.

\subsection{Purification of Alkenes from Alkyne Impurities}

To an oven-dried $10 \mathrm{~mL}$ screw-capped vial, alkyne $\mathbf{1 b}(0.05 \mathrm{mmol}), \mathbf{2 b}(5 \mathrm{mmol})$, ammoniaborane (0.15 mmol), Co@NGR catalyst (4 mol\%) and methanol $(1 \mathrm{~mL})$ were added under a gentle stream of argon. The reaction mixture was stirred for $24 \mathrm{~h}$ at $80^{\circ} \mathrm{C}$. After cooling to room temperature, the reaction mixture was filtered through a short pad of Celite and the solvent was removed in vacuo. The conversion alkyne and the yield of alkene were determined by gas chromatography. 


\section{Characterization Data}

(Z)-1,2-diphenylethene (2b) ${ }^{3}$

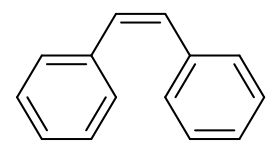

${ }^{1} \mathrm{H}$ NMR $\left(400 \mathrm{MHz}, \mathrm{CDCl}_{3}\right) \delta=7.30($ br m, $10 \mathrm{H}), 6.67$ (s, $\left.2 \mathrm{H}\right)$.

(Z)-1,2-bis(4-fluorophenyl)ethane $(2 \mathrm{c})^{4}$

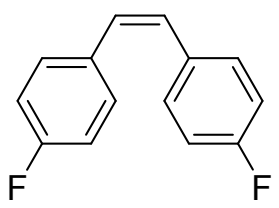

${ }^{1} \mathrm{H} \mathrm{NMR}\left(500 \mathrm{MHz}, \mathrm{CDCl}_{3}\right) \delta=7.24-7.15(\mathrm{~m}, 4 \mathrm{H}), 6.93(\mathrm{t}, J=8.8 \mathrm{~Hz}, 4 \mathrm{H}), 6.55(\mathrm{~s}, 2 \mathrm{H})$. ${ }^{13} \mathrm{C} \mathrm{NMR}\left(126 \mathrm{MHz}, \mathrm{CDCl}_{3}\right) \delta=161.8\left(\mathrm{~d}, J_{\mathrm{C}-\mathrm{F}}=246 \mathrm{~Hz}\right), 132.9,130.5\left(\mathrm{~d}, J_{\mathrm{C}-\mathrm{F}}=8.8 \mathrm{~Hz}\right)$, $129.1,115.1\left(\mathrm{~d}, J_{\mathrm{C}-\mathrm{F}}=21 \mathrm{~Hz}\right)$.

(Z)-1,2-bis(4-methoxyphenyl)ethane (2d) 5

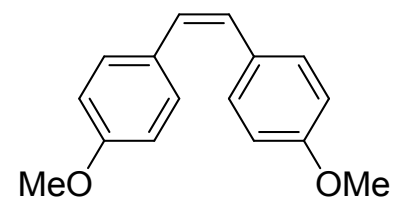

${ }^{1} \mathrm{H} \mathrm{NMR}\left(500 \mathrm{MHz}, \mathrm{CDCl}_{3}\right) \delta=7.23(\mathrm{~d}, J=8.8 \mathrm{~Hz}, 4 \mathrm{H}), 6.80(\mathrm{~d}, J=8.8 \mathrm{~Hz}, 4 \mathrm{H}), 6.47$ (s, 2 $\mathrm{H}), 3.81(\mathrm{~s}, 6 \mathrm{H}) .{ }^{13} \mathrm{C} \mathrm{NMR}\left(126 \mathrm{MHz}, \mathrm{CDCl}_{3}\right) \delta=158.5,130.0,129.3,128.4,113.7,113.6$, 55.1 .

(Z)-1-methyl-4-styrylbenzene (2e $)^{3}$

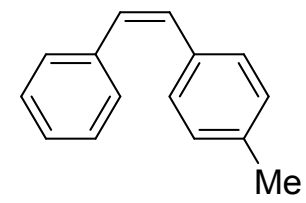


${ }^{1} \mathrm{H} \mathrm{NMR}\left(400 \mathrm{MHz}, \mathrm{CDCl}_{3}\right) \delta=7.40$ - $7.35(\mathrm{~m}, 2 \mathrm{H}), 7.35-7.21(\mathrm{~m}, 5 \mathrm{H}), 7.12(\mathrm{~d}, J=7.9 \mathrm{~Hz}$, $2 \mathrm{H}), 6.65$ (s, $2 \mathrm{H}), 2.40$ (s, $3 \mathrm{H}) .{ }^{13} \mathrm{C} \mathrm{NMR}\left(101 \mathrm{MHz}, \mathrm{CDCl}_{3}\right) \delta=137.5,136.8,134.3,130.2$, $129.5,128.9,128.8,128.8,128.2,126.9,21.2$.

(Z)-1-chloro-3-styrylbenzene $(2 \mathrm{~g})^{3}$

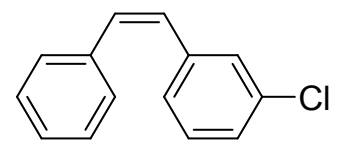

${ }^{1} \mathrm{H} \mathrm{NMR}\left(500 \mathrm{MHz}, \mathrm{CDCl}_{3}\right) \delta=7.32-7.23(\mathrm{~m}, 6 \mathrm{H}), 7.23-7.13(\mathrm{~m}, 3 \mathrm{H}), 6.70(\mathrm{~d}, J=12.2$ $\mathrm{Hz}, 1 \mathrm{H}), 6.57$ (d, $J=12.2 \mathrm{~Hz}, 1 \mathrm{H})$.

\section{(Z)-2-fluoro-4-styrylbenzonitrile (2i)}

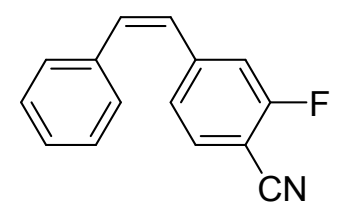

${ }^{1} \mathrm{H}$ NMR (500 MHz, $\left.\mathrm{CDCl}_{3}\right) \delta=7.30$ (br. s., $4 \mathrm{H}$ ), 7.22 (br. s., $\left.2 \mathrm{H}\right), 7.17$ - 7.01 (m, $\left.3 \mathrm{H}\right), 6.85$ $(\mathrm{d}, J=12.2 \mathrm{~Hz}, 1 \mathrm{H}), 6.55(\mathrm{~d}, J=12.2 \mathrm{~Hz}, 1 \mathrm{H})$.

\section{(Z)-methyl 4-styrylbenzoate $(2 \mathrm{k})^{3}$}

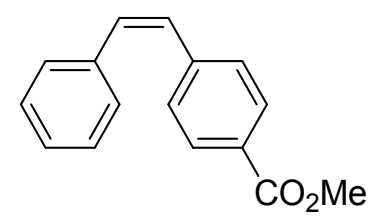

${ }^{1} \mathrm{H}$ NMR $\left(500 \mathrm{MHz}, \mathrm{CDCl}_{3}\right) \delta=7.92(\mathrm{~d}, J=8.4 \mathrm{~Hz}, 2 \mathrm{H}), 7.33(\mathrm{~d}, J=8.0 \mathrm{~Hz}, 2 \mathrm{H}), 7.28-7.21$ $(\mathrm{m}, 5 \mathrm{H}), 6.74(\mathrm{~d}, J=12.2 \mathrm{~Hz}, 1 \mathrm{H}), 6.64(\mathrm{~d}, J=12.2 \mathrm{~Hz}, 1 \mathrm{H}), 3.95-3.87(\mathrm{~m}, 3 \mathrm{H}) .{ }^{13} \mathrm{C} \mathrm{NMR}$ $\left(126 \mathrm{MHz}, \mathrm{CDCl}_{3}\right) \delta=166.9,142.1,136.6,132.2,129.5,129.2,128.8,128.3,127.5,52.0$. HRMS (EI): $m / z$ Calcd for $\mathrm{C}_{16} \mathrm{H}_{15} \mathrm{O}_{2}$ : 239.1072; Found: 239.1067. 


\section{(Z)-2-styrylthiophene $(2 \mathrm{~m})^{3}$}

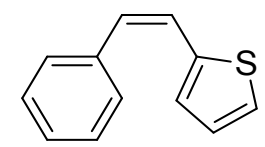

${ }^{1} \mathrm{H}$ NMR $\left(500 \mathrm{MHz}, \mathrm{CDCl}_{3}\right) \delta=7.42-7.35(\mathrm{~m}, 5 \mathrm{H}), 7.12(\mathrm{~d}, J=5.0 \mathrm{~Hz}, 1 \mathrm{H}), 7.00(\mathrm{~d}, J=3.4$ Hz, $1 \mathrm{H}), 6.92(\mathrm{dd}, J=3.8,5.0 \mathrm{~Hz}, 1 \mathrm{H}), 6.73(\mathrm{~d}, J=11.8 \mathrm{~Hz}, 1 \mathrm{H}), 6.61(\mathrm{~d}, J=11.8 \mathrm{~Hz}, 1 \mathrm{H})$.

\section{(Z)-tert-butyldimethyl(4-phenylbut-3-enyloxy)silane (2n)}

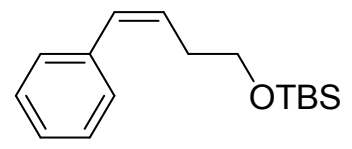

${ }^{1} \mathrm{H}$ NMR $\left(500 \mathrm{MHz}, \mathrm{CDCl}_{3}\right) \delta=7.43-7.30(\mathrm{~m}, 4 \mathrm{H}), 7.24(\mathrm{dt}, J=11.8,5.8 \mathrm{~Hz}, 1 \mathrm{H}), 6.53(\mathrm{~d}$, $J=10.0 \mathrm{~Hz}, 1 \mathrm{H}), 5.73(\mathrm{td}, J=5.0,10.0 \mathrm{~Hz}, 1 \mathrm{H}), 3.74(\mathrm{t}, J=6.7 \mathrm{~Hz}, 2 \mathrm{H}), 2.64-2.54(\mathrm{~m}, 2$ $\mathrm{H}), 0.95-0.90(\mathrm{~m}, 10 \mathrm{H}), 0.19-0.03(\mathrm{~m}, 7 \mathrm{H}) .{ }^{13} \mathrm{C} \mathrm{NMR}\left(126 \mathrm{MHz}, \mathrm{CDCl}_{3}\right) \delta=137.5,130.4$, 129.0, 128.7, 128.1, 126.6, 62.9, 32.2, 25.9, 18.4. HRMS (EI): $m / z$ Calcd for $\mathrm{C}_{16} \mathrm{H}_{17} \mathrm{OSi}$ : 263.1831; Found: 263.1826.

\section{(Z)-3-phenylprop-2-en-1-ol (2o) ${ }^{3}$}

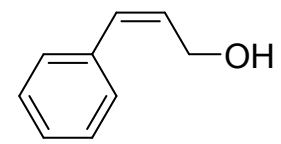

${ }^{1} \mathrm{H}$ NMR $\left(200 \mathrm{MHz}, \mathrm{CDCl}_{3}\right) \delta=7.39-7.10(\mathrm{~m}, 5 \mathrm{H}), 6.54(\mathrm{~d}, J=11.8 \mathrm{~Hz}, 1 \mathrm{H}), 5.85(\mathrm{td}, J=$ 11.8, $6.8 \mathrm{~Hz}, 1 \mathrm{H}), 4.41$ (d, $J=6.2 \mathrm{~Hz}, 2 \mathrm{H}), 2.22$ (br. s., $1 \mathrm{H})$.

\section{1-methoxy-4-vinylbenzene (5a)}<smiles>C=Cc1ccc(OC)cc1</smiles>

${ }^{1} \mathrm{H} \mathrm{NMR}\left(200 \mathrm{MHz}, \mathrm{CDCl}_{3}\right) \delta=7.45-7.30(\mathrm{~m}, 2 \mathrm{H}), 6.99-6.82(\mathrm{~m}, 2 \mathrm{H}), 6.70(\mathrm{dd}, J=10.9$, $17.6 \mathrm{~Hz}, 1 \mathrm{H}), 5.64$ (dd, $J=1.0,17.6 \mathrm{~Hz}, 1 \mathrm{H}), 5.16$ (dd, $J=1.0,10.9 \mathrm{~Hz}, 1 \mathrm{H}), 3.89$ - 3.78 (m, $3 \mathrm{H})$. 


\section{1-fluoro-4-vinylbenzene (5b)}<smiles>C=Cc1ccc(F)cc1</smiles>

${ }^{1} \mathrm{H}$ NMR $\left(200 \mathrm{MHz}, \mathrm{CDCl}_{3}\right) \delta=7.56-7.34(\mathrm{~m}, 2 \mathrm{H}), 7.19-6.93(\mathrm{~m}, 2 \mathrm{H}), 6.72(\mathrm{dd}, J=10.9$, $17.6 \mathrm{~Hz}, 1 \mathrm{H}), 5.70$ (d, $J=17.6 \mathrm{~Hz}, 1 \mathrm{H}), 5.26$ (d, $J=10.9 \mathrm{~Hz}, 1 \mathrm{H}) .{ }^{13} \mathrm{C}$ NMR $(50 \mathrm{MHz}$, CHLOROFORM-d) $\delta=162.4\left(\mathrm{~d}, J_{\mathrm{C}-\mathrm{F}}=245 \mathrm{~Hz}\right), 135.6,133.6\left(\mathrm{~d}, J_{\mathrm{C}-\mathrm{F}}=5 \mathrm{~Hz}\right), 127.7\left(\mathrm{~d}, J_{\mathrm{C}-\mathrm{F}}=\right.$ $5 \mathrm{~Hz}), 115.3\left(\mathrm{~d}, J_{\mathrm{C}-\mathrm{F}}=20 \mathrm{~Hz}\right), 113.3$.

\section{1-methyl-4-vinylbenzene (5c)}<smiles>C=Cc1ccc(C)cc1</smiles>

${ }^{1} \mathrm{H} \mathrm{NMR}\left(200 \mathrm{MHz}, \mathrm{CDCl}_{3}\right) \delta=7.47-7.31(\mathrm{~m}, J=8.2 \mathrm{~Hz}, 2 \mathrm{H}), 7.25-7.04(\mathrm{~m}, J=8.0 \mathrm{~Hz}, 2$ H), $6.76(\mathrm{dd}, J=10.9,17.6 \mathrm{~Hz}, 1 \mathrm{H}), 5.77(\mathrm{dd}, J=1.0,17.6 \mathrm{~Hz}, 1 \mathrm{H}), 5.25$ (dd, $J=1.0,10.9$ $\mathrm{Hz}, 1 \mathrm{H}), 2.41(\mathrm{~s}, 3 \mathrm{H})$.

\section{1-tert-butyl-4-vinylbenzene (5d)}<smiles>C=Cc1ccc(C(C)(C)C)cc1</smiles>

${ }^{1} \mathrm{H}$ NMR $\left(200 \mathrm{MHz}, \mathrm{CDCl}_{3}\right) \delta=7.55-7.59(\mathrm{~m}, 4 \mathrm{H}), 6.86-7.01(\mathrm{~m}, 1 \mathrm{H}), 5.93(\mathrm{dd}, J=1.0$, $17.6 \mathrm{~Hz}, 1 \mathrm{H}), 5.41$ (dd, $J=1.0,10.9 \mathrm{~Hz}, 1 \mathrm{H}), 1.53(\mathrm{~s}, 9 \mathrm{H})$.

\section{1-chloro-3-vinylbenzene (5e)}<smiles>C=Cc1cccc(Cl)c1</smiles>

${ }^{1} \mathrm{H} \mathrm{NMR}\left(200 \mathrm{MHz}, \mathrm{CDCl}_{3}\right) \delta=7.44-7.32(\mathrm{~m}, 1 \mathrm{H}), 7.32-7.08(\mathrm{~m}, 3 \mathrm{H}), 6.65(\mathrm{dd}, J=10.9$, $17.6 \mathrm{~Hz}, 1 \mathrm{H}), 5.75$ (d, $J=17.6 \mathrm{~Hz}, 1 \mathrm{H}), 5.29$ (d, $J=10.9 \mathrm{~Hz}, 1 \mathrm{H})$. 


\section{References}

1. Armarego, W. L. F.; Perrin, D. D. Purification of Laboratory Chemicals. Pergamon Press, Oxford, 1988; ed 3.

2. Marcano, D. C.; Kosynkin, D. V.; Berlin, J. M.; Sinitskii, A.; Sun, Z.; Slesarev, A.; Alemany, L. B.; Lu, W.; Tour, J. M. Improved Synthesis of Graphene Oxide. ACS Nano, 2010, 4, 4806-4814.

3. Fu, S.; Chen, N.-Y.; Liu, X.; Shao, Z.; Luo S.-P.; Liu, Q. Ligand-Controlled CobaltCatalyzed Transfer Hydrogenation of Alkynes: Stereodivergent Synthesis of $Z$ - and E-Alkenes. J. Am. Chem. Soc. 2016, 138, 8588-8594.

4. Xiao, B.; Niu, Z.; Wang, Y.-G.; Jia, W.; Shang, J.; Zhang, L.; Wang, D.; Fu, Y.; Zeng, J.; He, W.; Wu, K.; Li, J.; Yang, J.; Liu, L.; Li, Y. J. Am. Chem. Soc. 2015, 137, 3791-3794.

5. Ilies, L.; Yoshida, T.; Nakamura, E. Iron-Catalyzed Chemo- and Stereoselective Hydromagnesiation of Diarylalkynes and Diynes. J. Am. Chem. Soc. 2012, 134, 16951-16954. 
7. Table S2. Literature report on cobalt-catalyzed hydrogenation of alkynes

\begin{tabular}{|c|c|c|c|c|}
\hline No & $\begin{array}{l}\text { Hydrogen } \\
\text { source }\end{array}$ & Reaction Conditions & Reference & Disadvantages \\
\hline 1 & $\mathrm{NH}_{3} \mathrm{BH}_{3}$ & 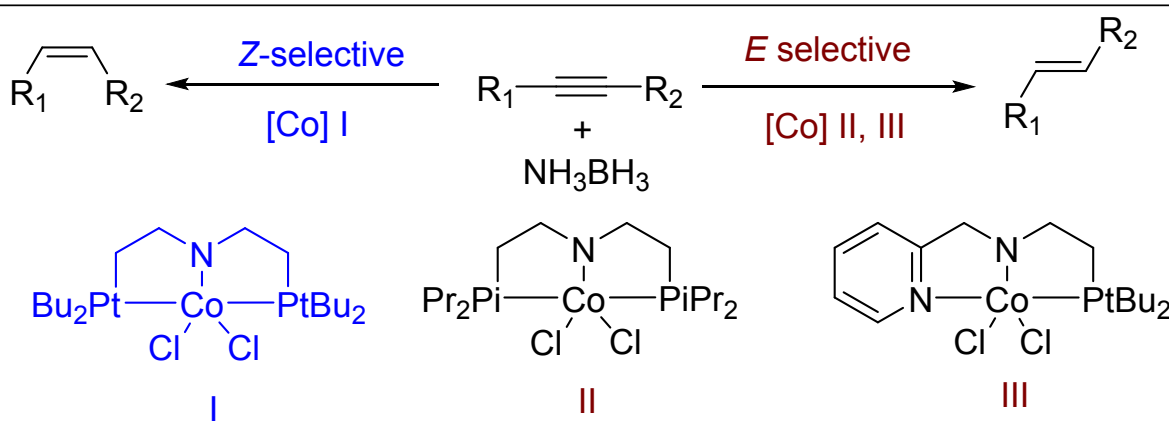 & $\begin{array}{l}\text { J. Am. Chem. } \\
\text { Soc. } 2016,138 \\
8588-8594 .\end{array}$ & $\begin{array}{l}* \text { Recyclability of the } \\
\text { catalyst } \\
* \text { Sophisticated ligand } \\
\text { synthesis } \\
* \text { Air sensitive ligand } \\
\text { * Recyclability and } \\
\text { reusability }\end{array}$ \\
\hline 2 & $\mathrm{H}_{2}$ & $\mathrm{R}_{1}=\mathrm{R}_{2} \stackrel{\text { [Co] } 3 \mathrm{~mol} \%}{4 \mathrm{~atm} \mathrm{\textrm {H } _ { 2 }}}$ & $\begin{array}{l}\text { J. Am. Chem. } \\
\text { Soc. } 2016,138 \text {, } \\
13700-13705\end{array}$ & $\begin{array}{l}* \text { Works under } \\
\text { hydrogen pressure } \\
* \text { Sophisticated ligand } \\
\text { synthesis } \\
* \text { Only E can be } \\
\text { obtained } \\
* \text { Recyclability and } \\
\text { reusability }\end{array}$ \\
\hline 3 & $\mathrm{H}_{2}$ & 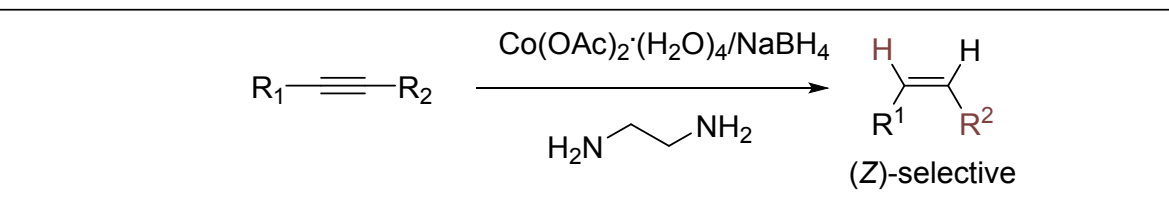 & $\begin{array}{l}\text { Chem. } \\
\text { Commun., 2017, } \\
\text { 53, 4612-4615 }\end{array}$ & $\begin{array}{l}* \text { Recyclability and } \\
\text { reusability }\end{array}$ \\
\hline
\end{tabular}




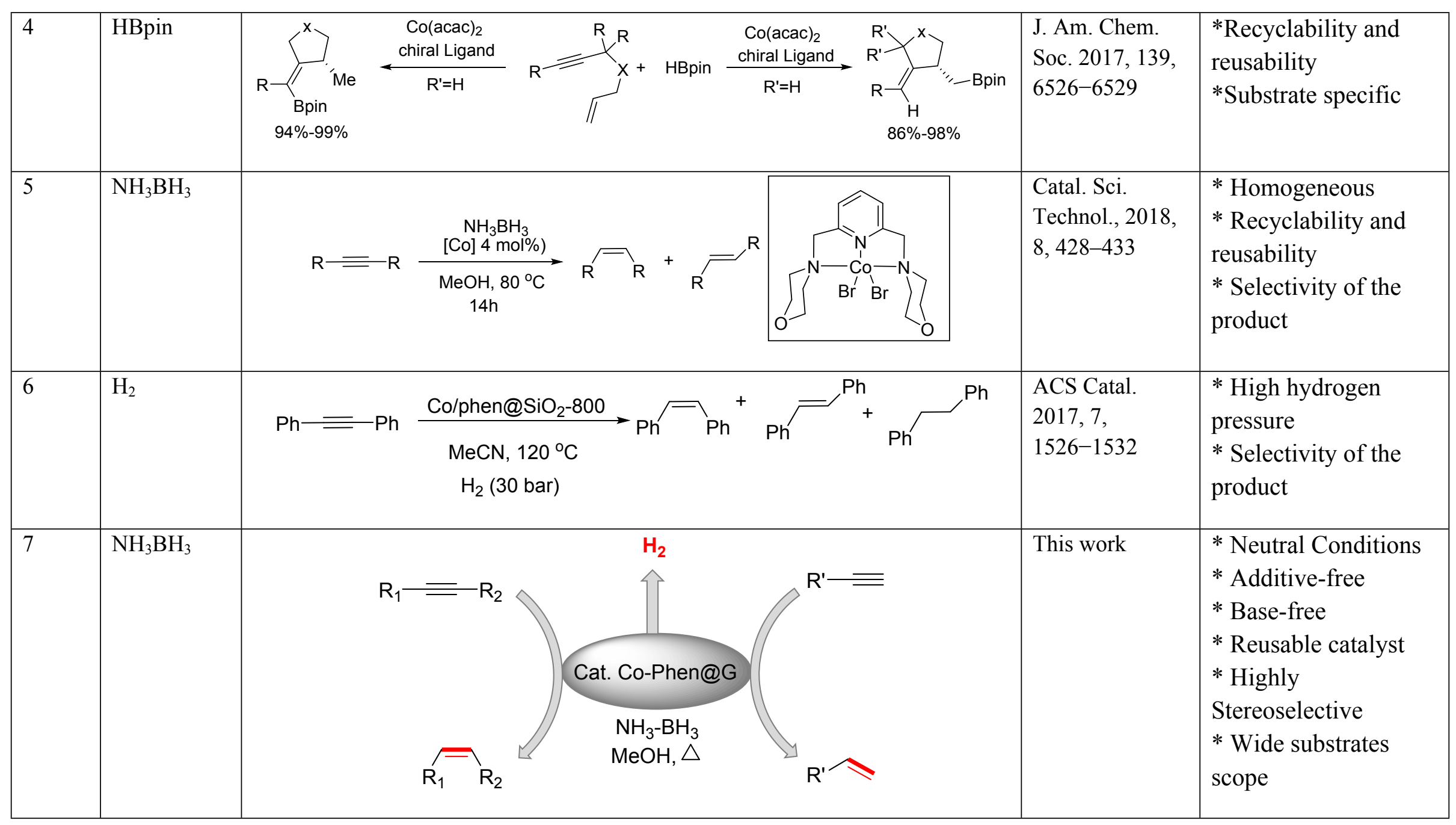


8. Copies of Spectra

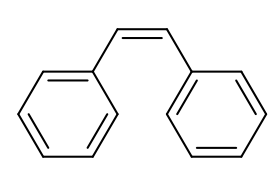

$2 b$

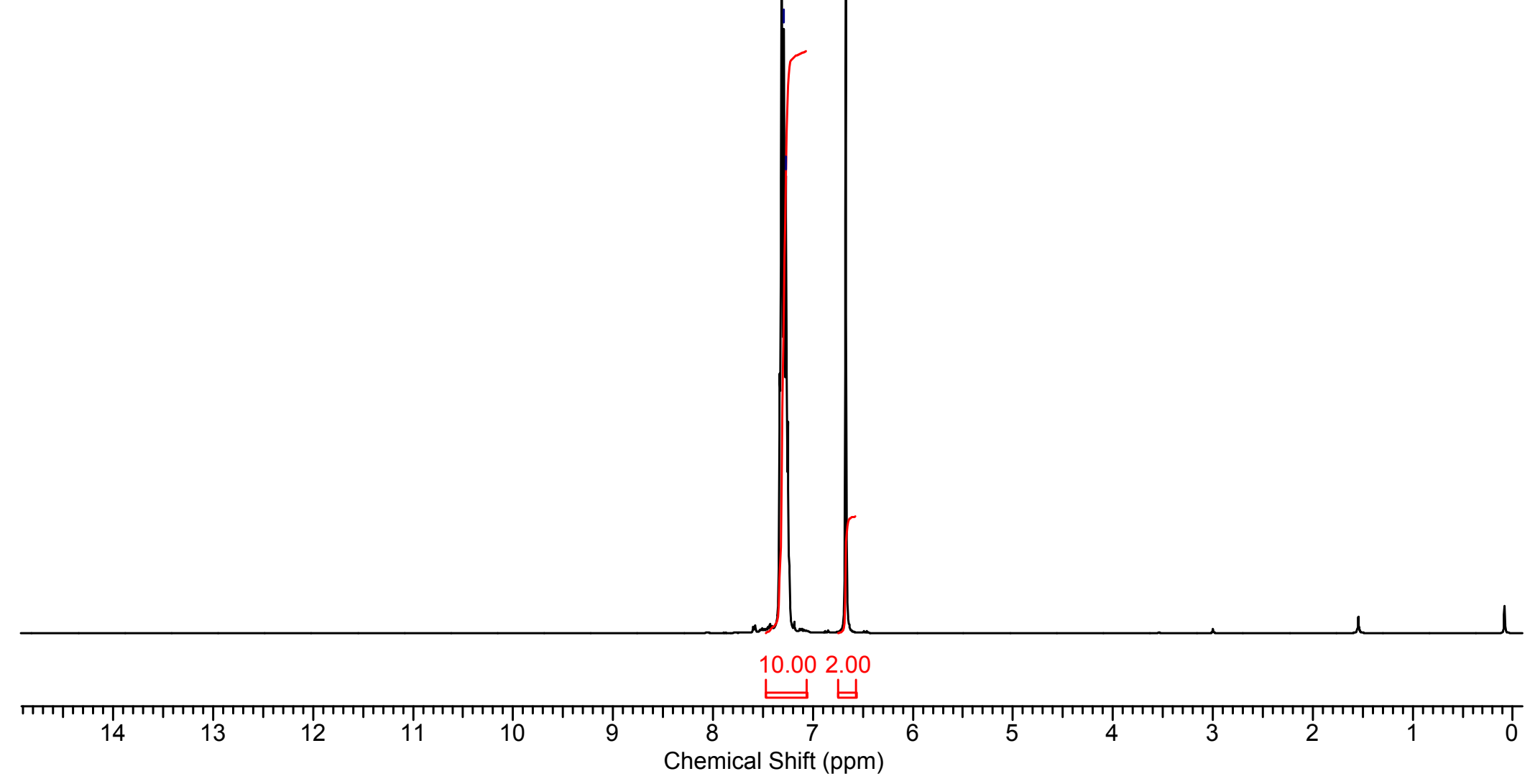

Figure S14. ${ }^{1} \mathrm{H}$ NMR of $\mathbf{2 b}$ 


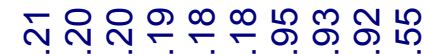

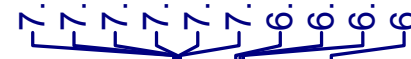
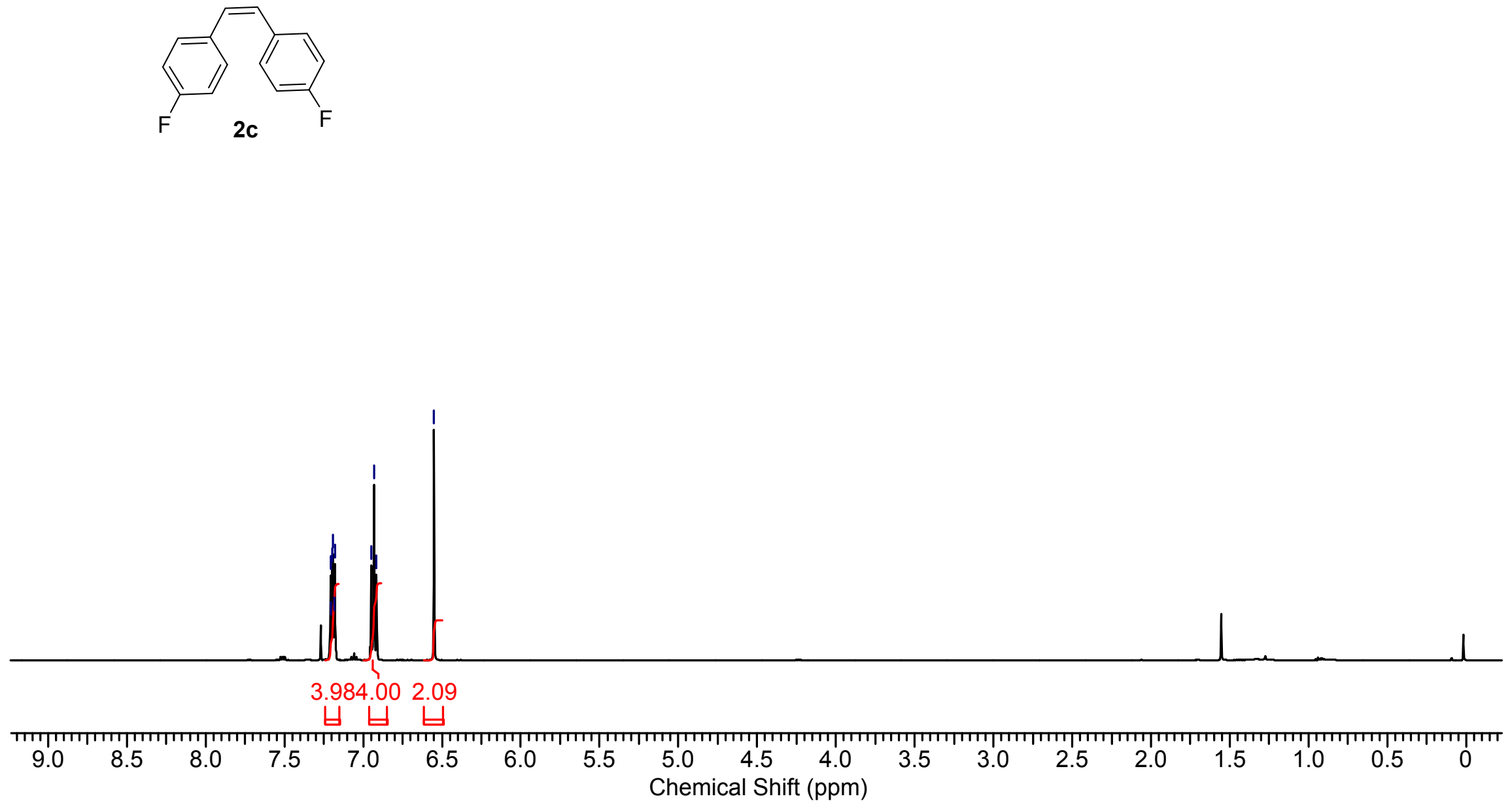

Figure S15. ${ }^{1} \mathrm{H}$ NMR of $2 \mathrm{c}$ 

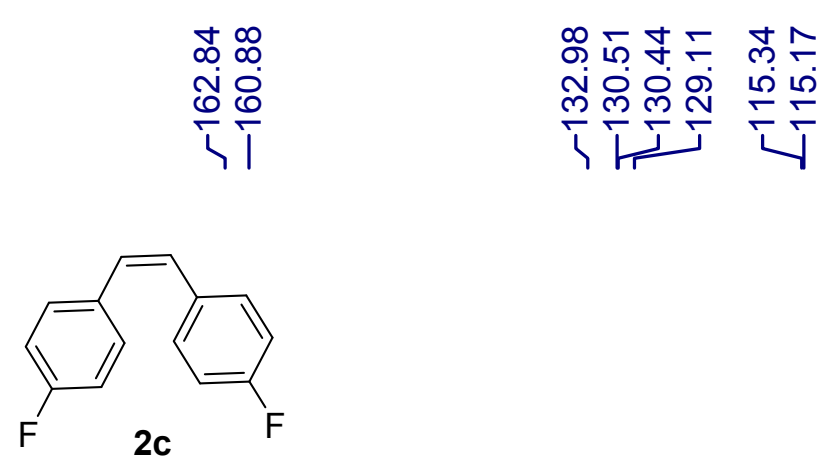

กิ

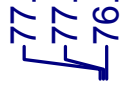

$2 c$

H

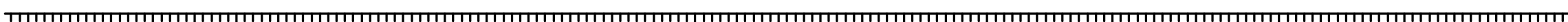

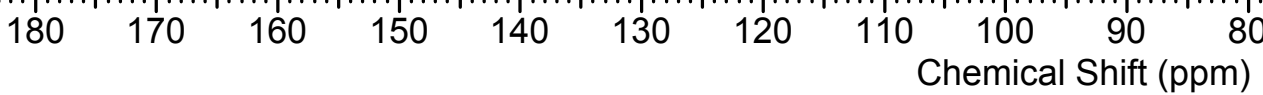

Figure S16. ${ }^{13} \mathrm{C}$ NMR of $2 \mathrm{c}$ 


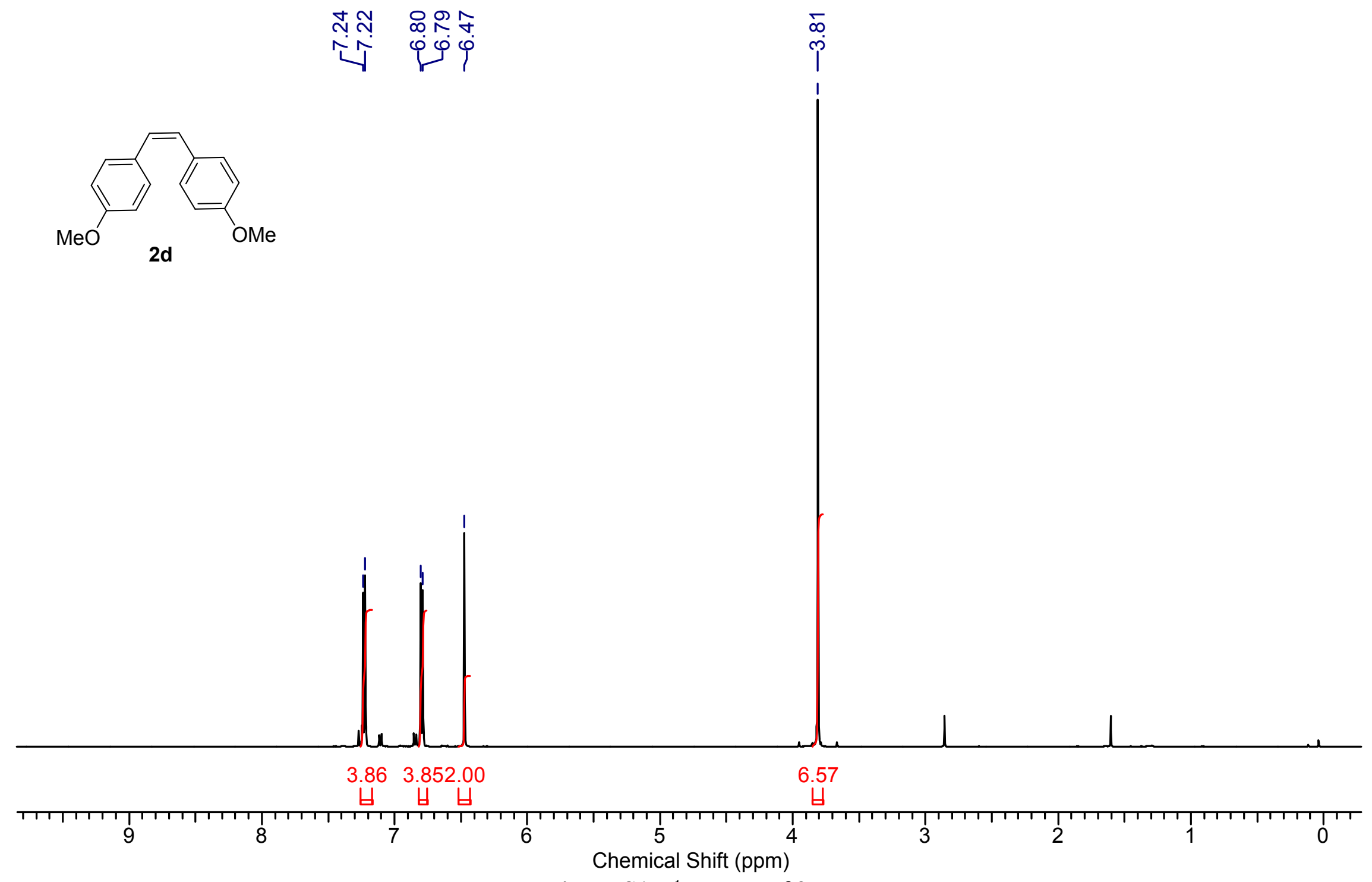

Figure S17. ${ }^{1} \mathrm{H}$ NMR of $2 \mathrm{~d}$ 


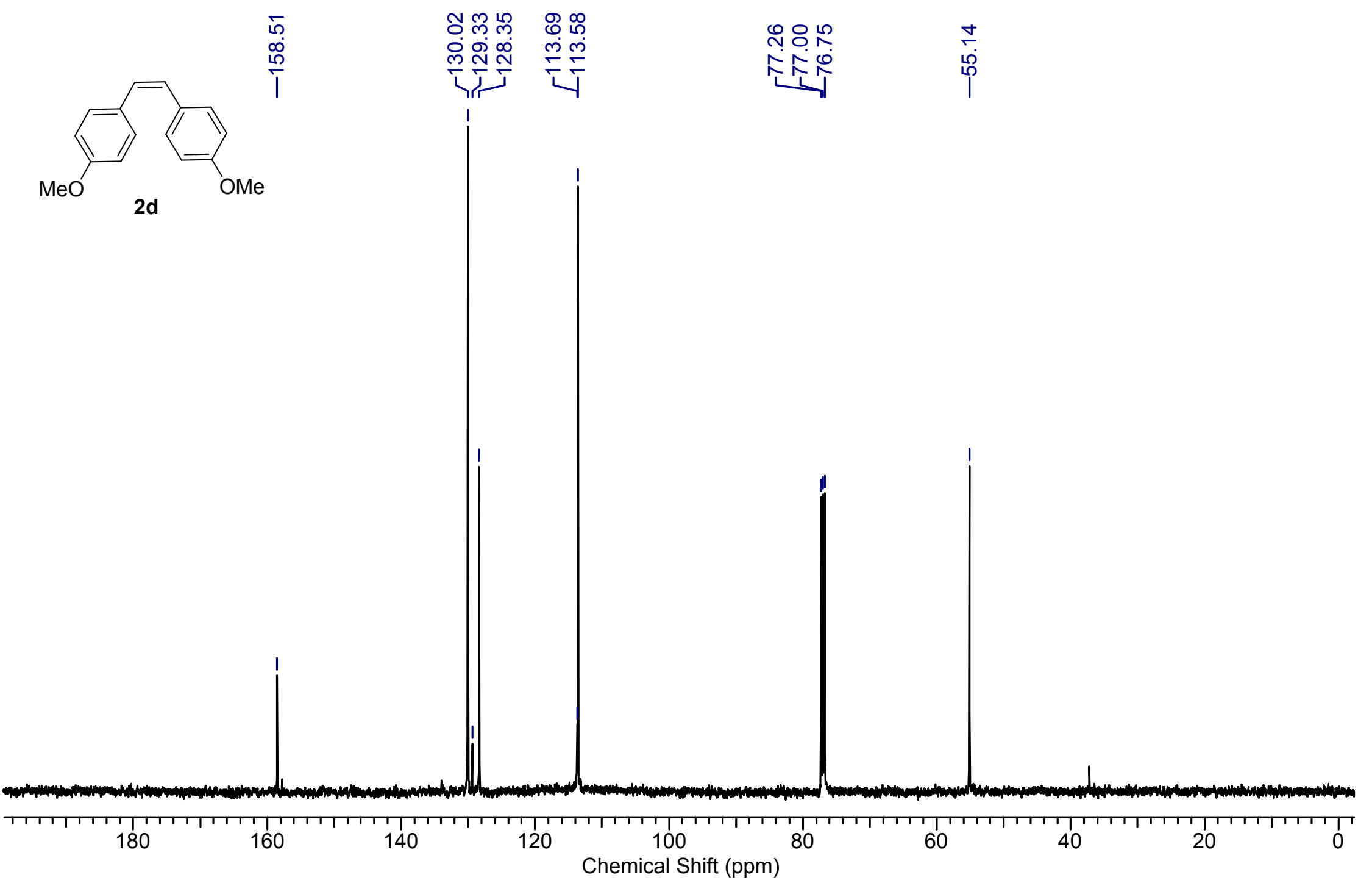

Figure S18. ${ }^{13} \mathrm{C}$ NMR of $\mathbf{2 d}$ 


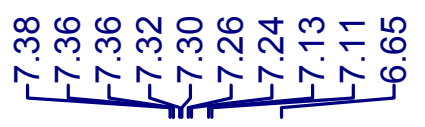
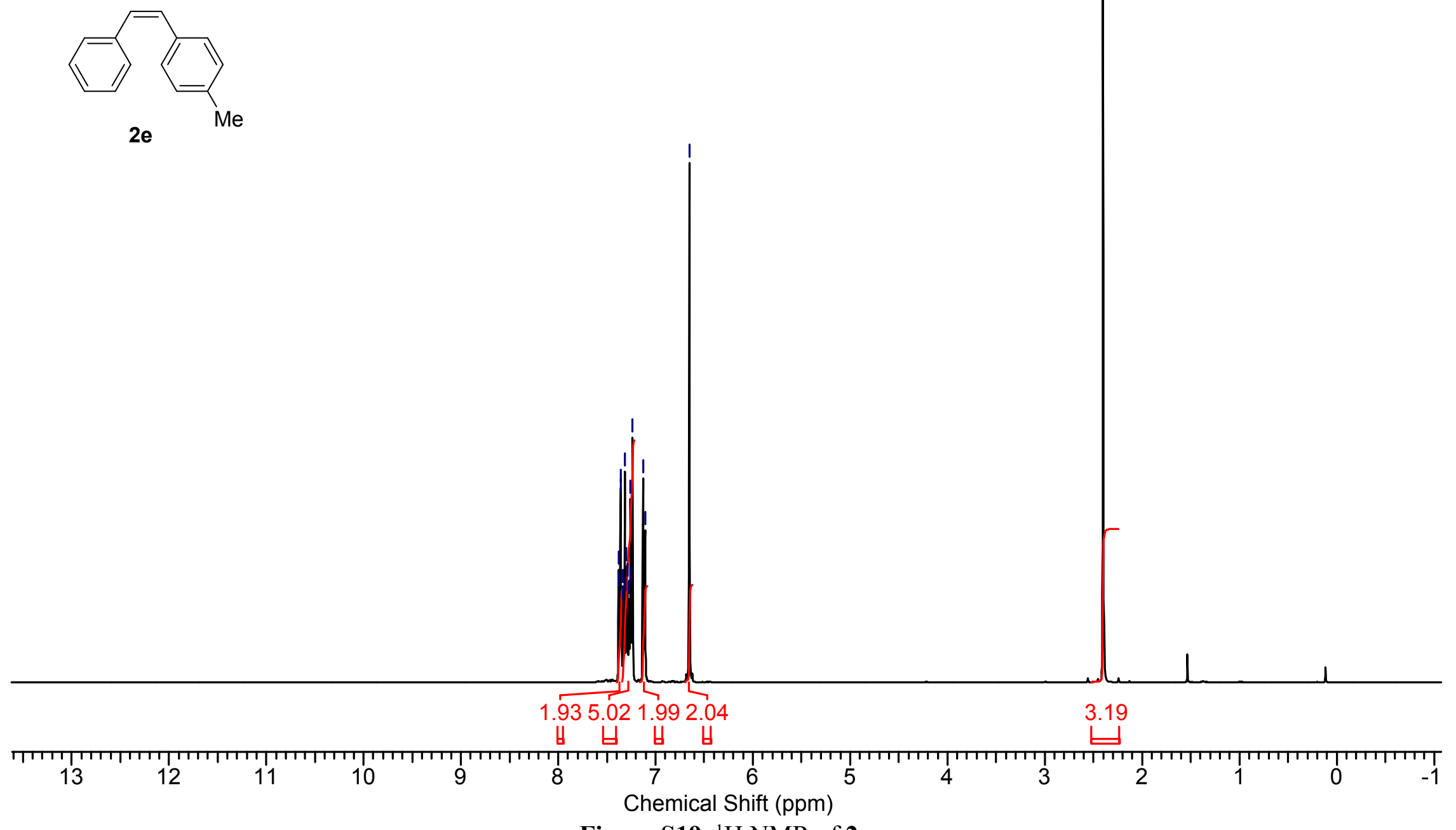

Figure S19. ${ }^{1} \mathrm{H}$ NMR of 2e

S34 


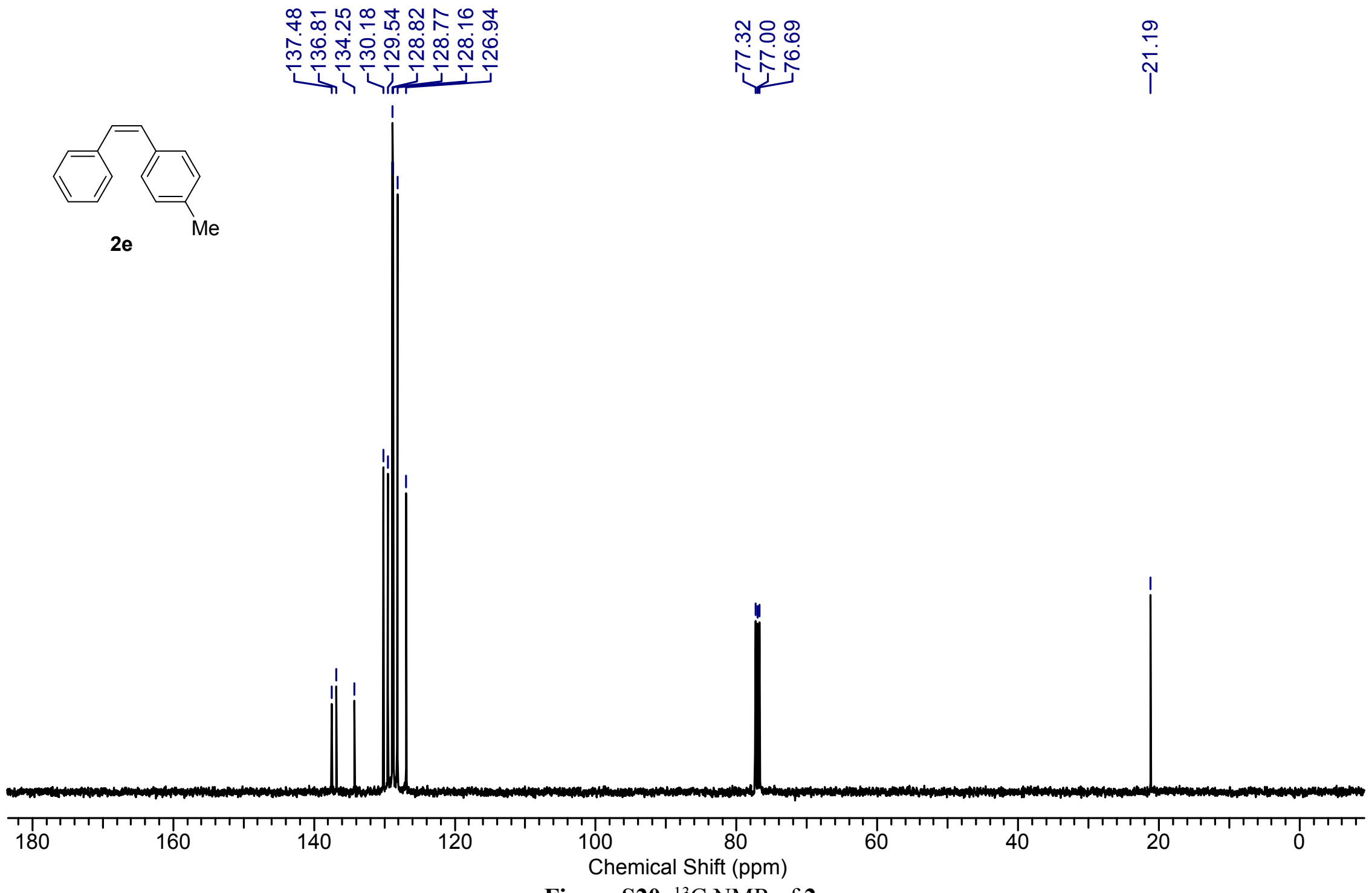

Figure S20. ${ }^{13} \mathrm{C}$ NMR of $2 \mathrm{e}$ 


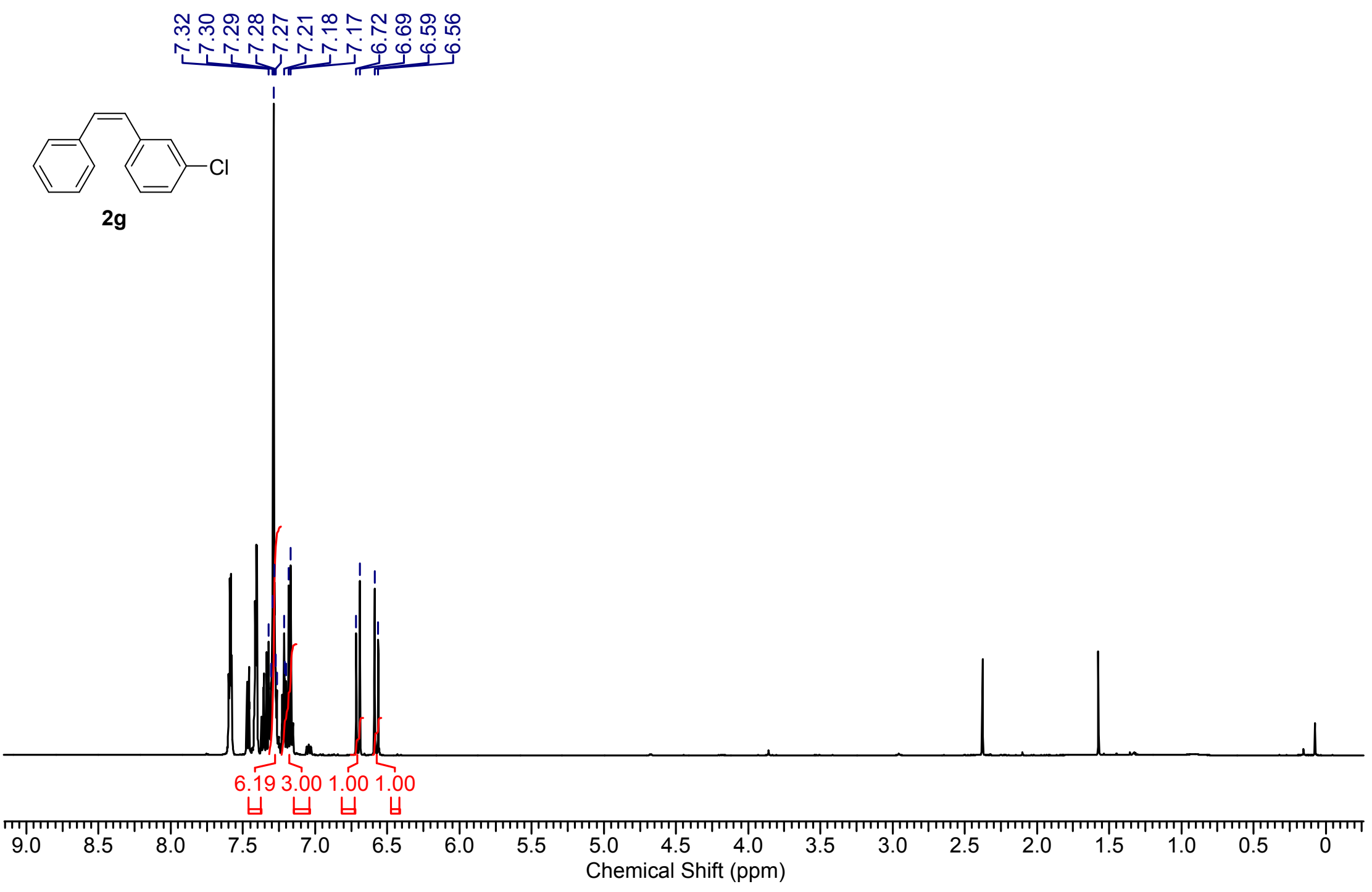

Figure S21. ${ }^{1} \mathrm{H}$ NMR of $\mathbf{2 g}$ 


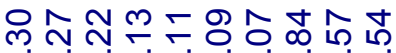

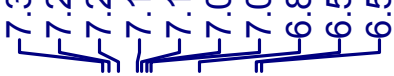
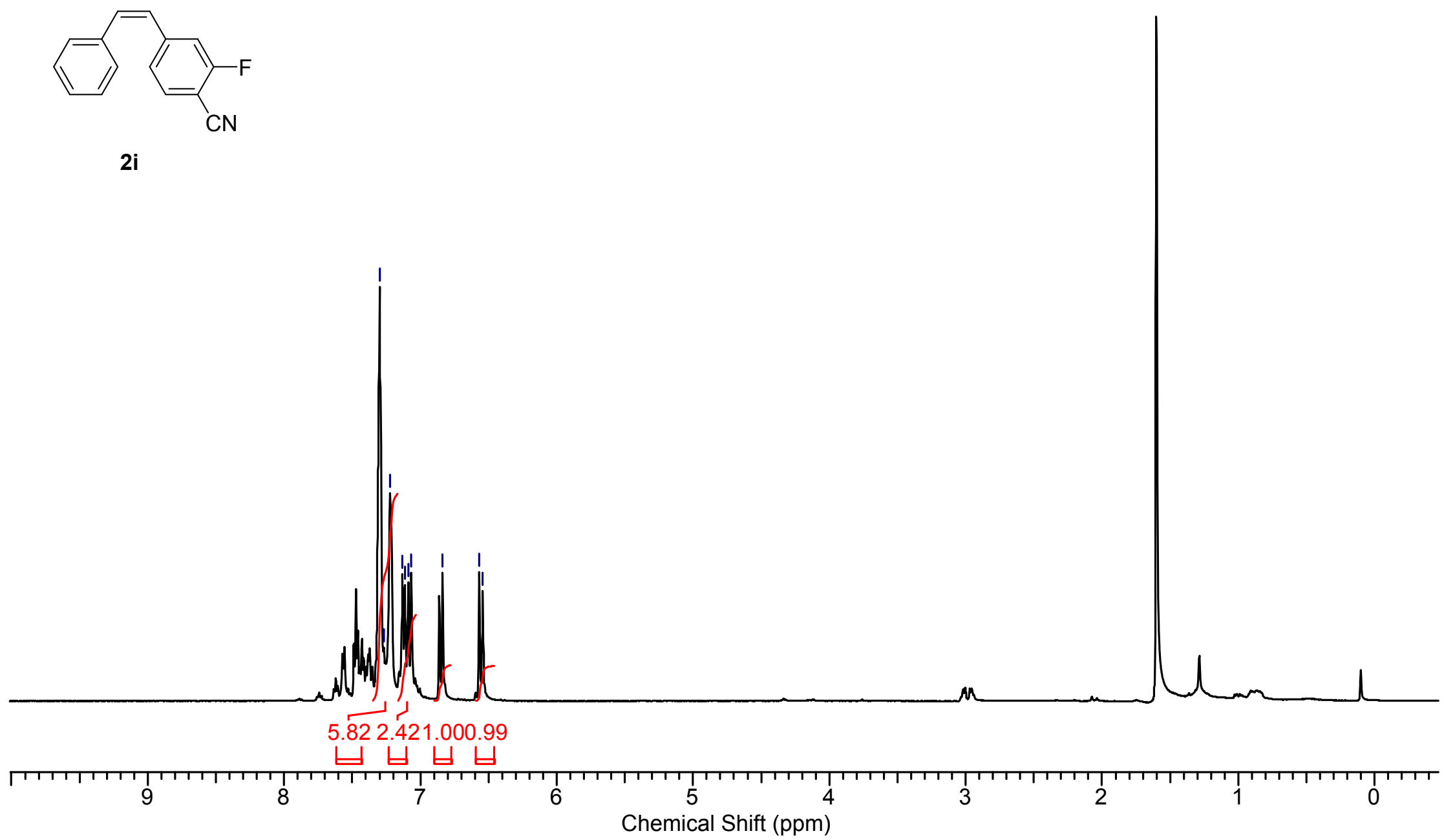

Figure S22. ${ }^{1} \mathrm{H}$ NMR of $\mathbf{2 i}$ 

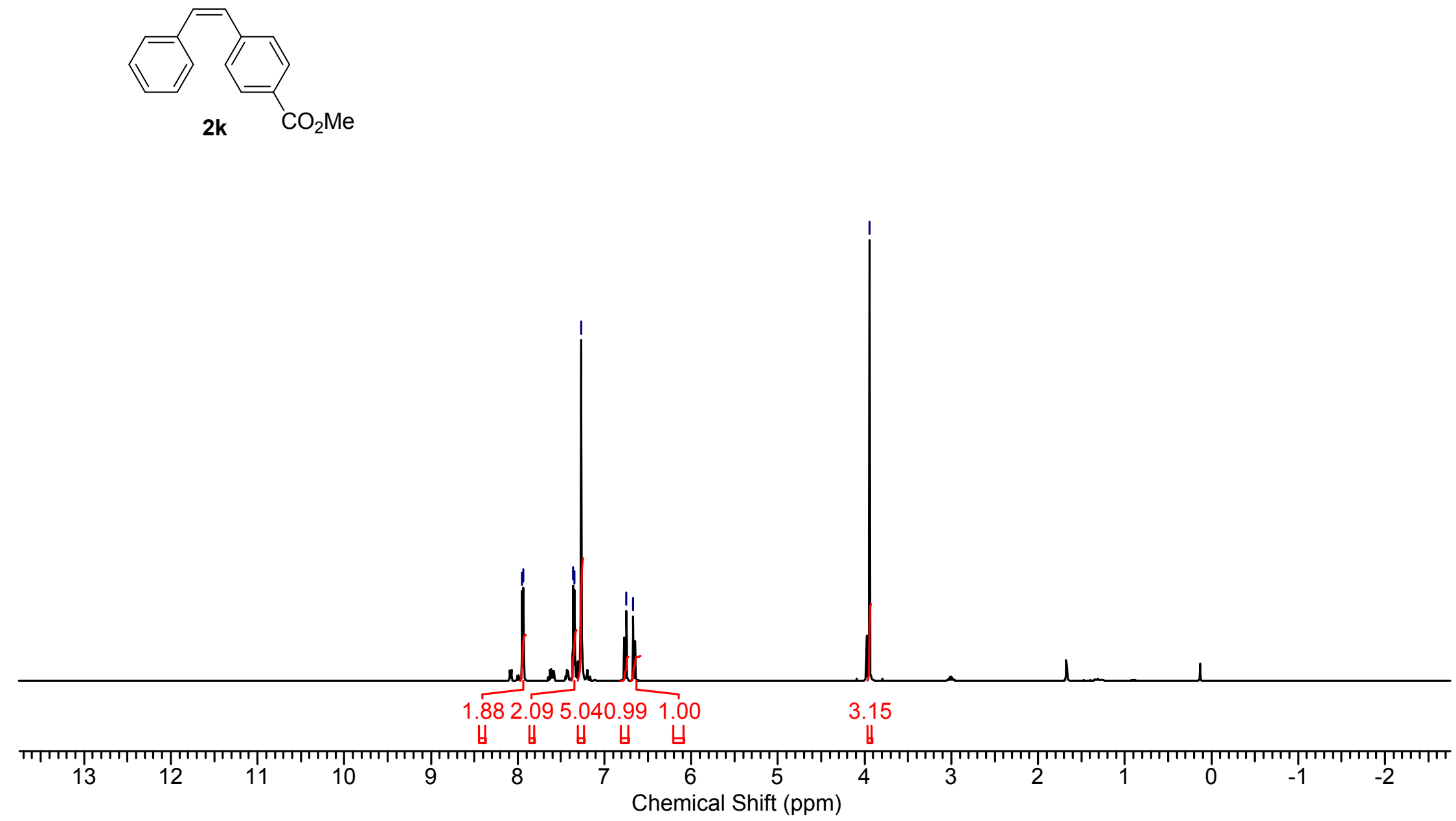

Figure S23. ${ }^{1} \mathrm{H}$ NMR of $\mathbf{2 k}$ 


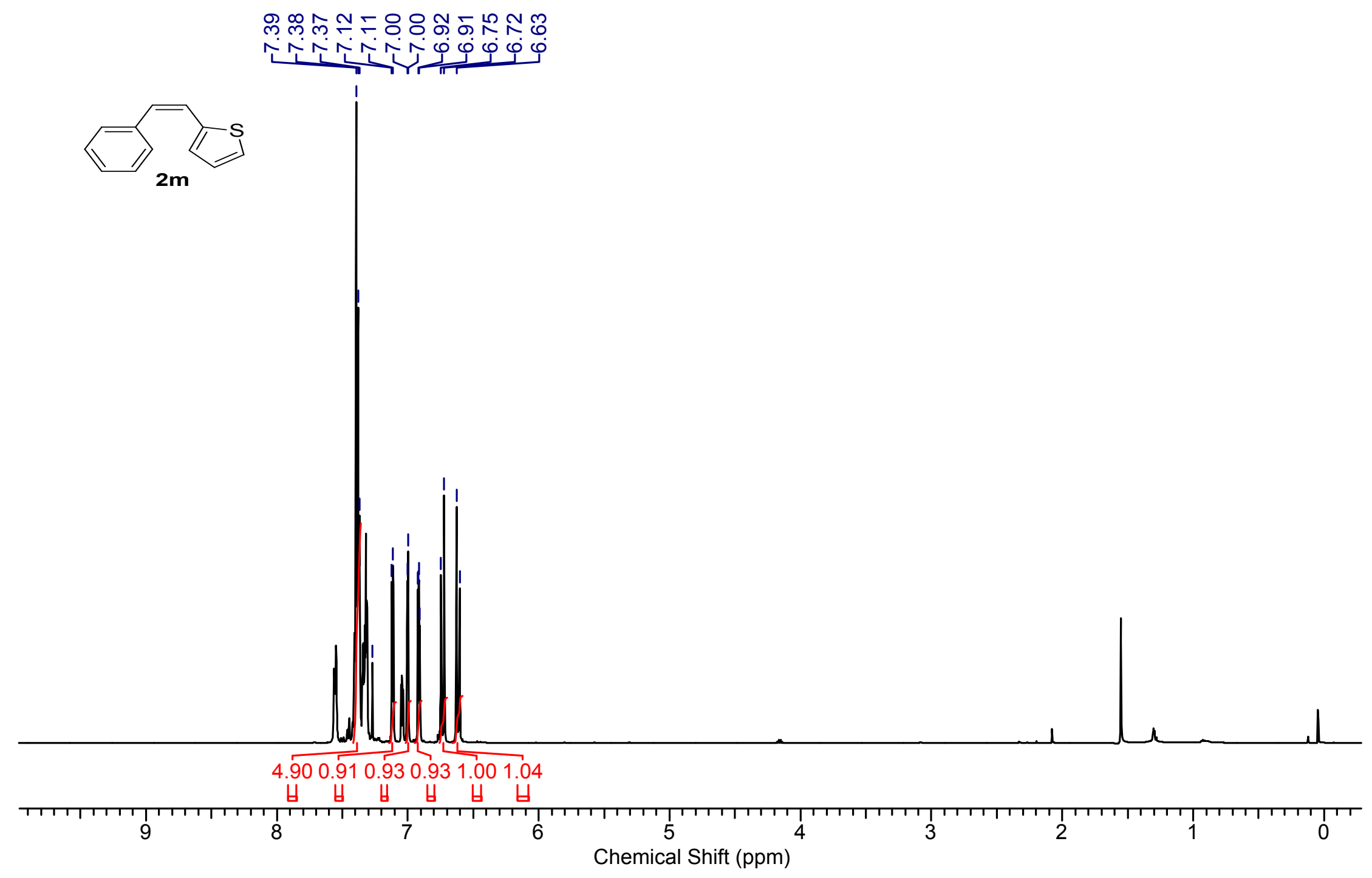

Figure S24. ${ }^{1} \mathrm{H}$ NMR of $\mathbf{2 m}$ 


\section{CHLOROFORM-d}

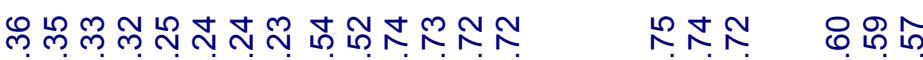
先公公公

min

نูin

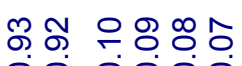

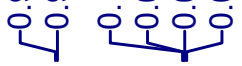

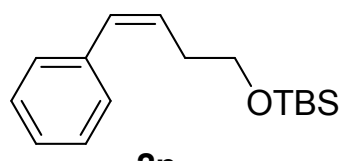

$2 n$

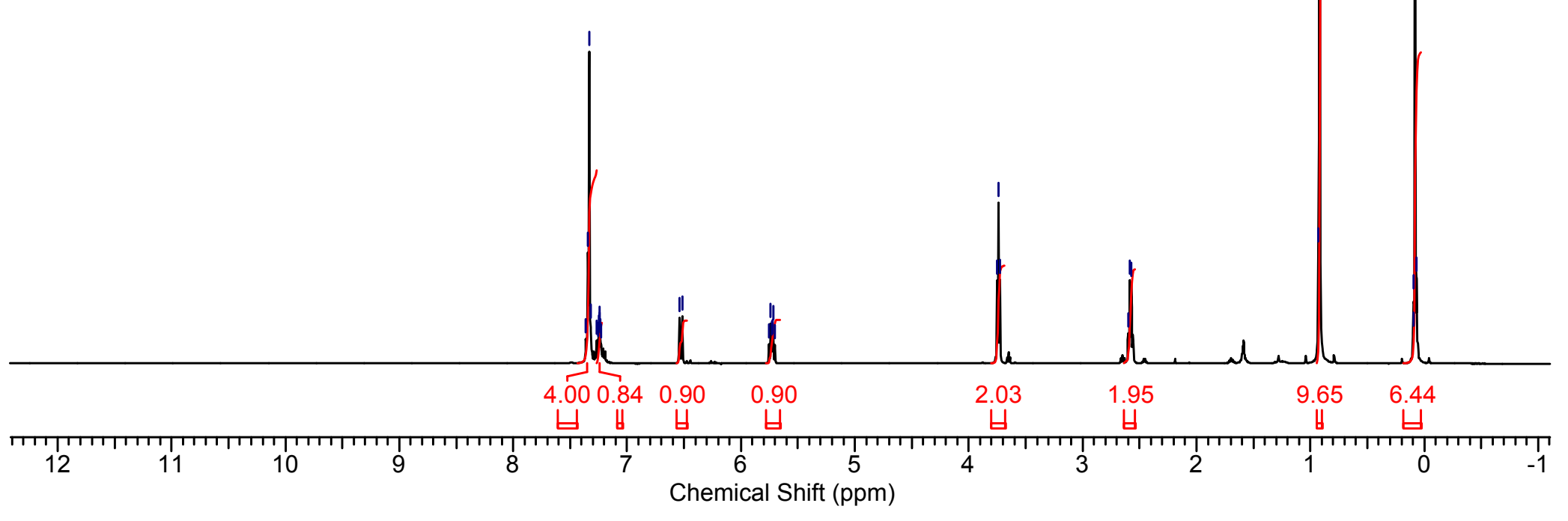

Figure S25. ${ }^{1} \mathrm{H}$ NMR of 2 n 


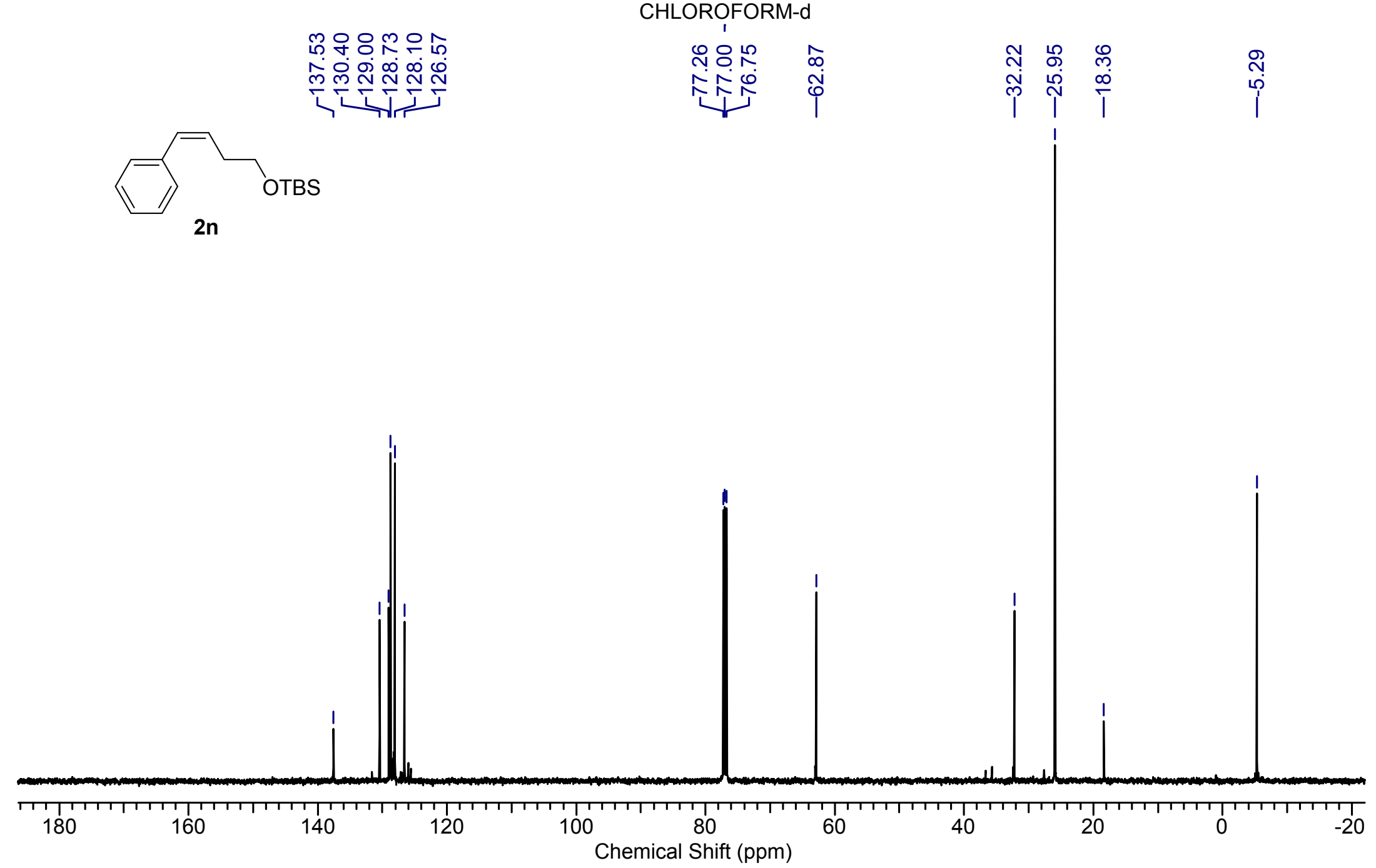

CHLOROFORM-d

Figure S26. ${ }^{13} \mathrm{C}$ NMR of $\mathbf{2 n}$ 


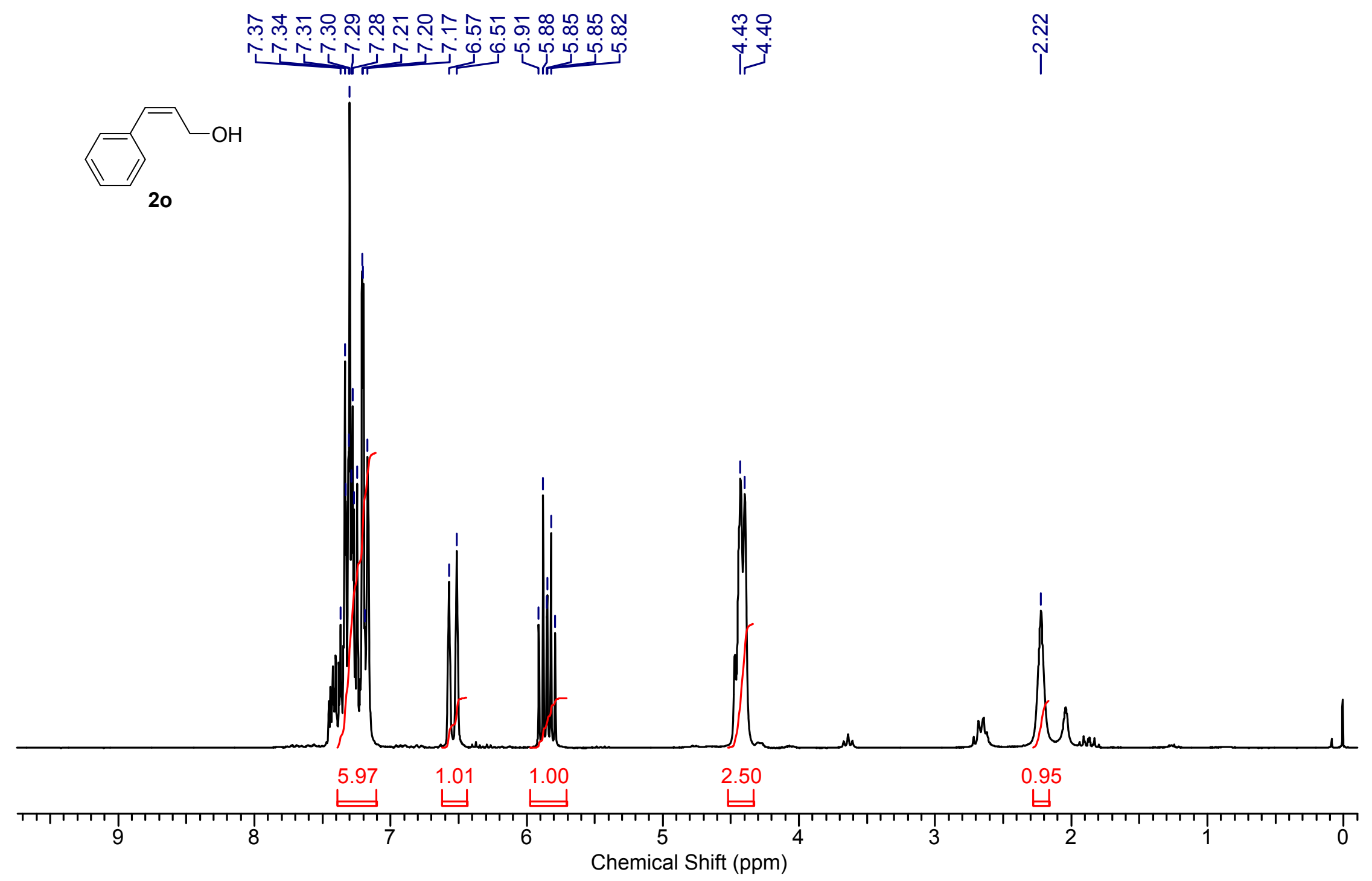

Figure S27. ${ }^{1} \mathrm{H}$ NMR of 20 


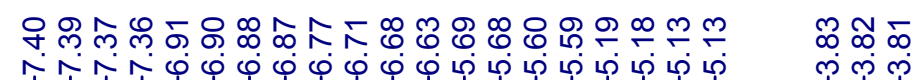

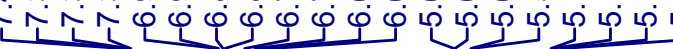

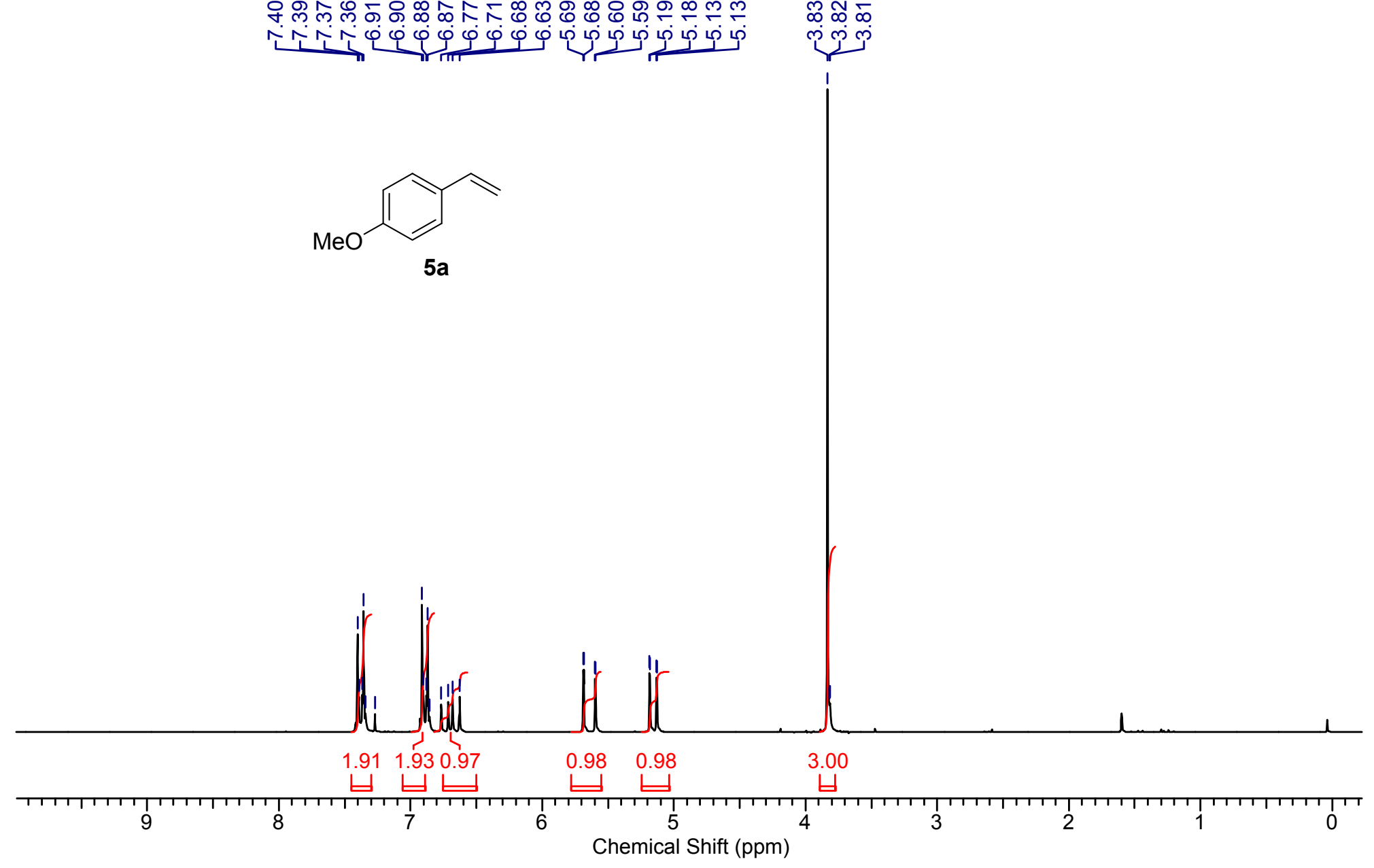

Figure S28. ${ }^{1} \mathrm{H}$ NMR of 5a 


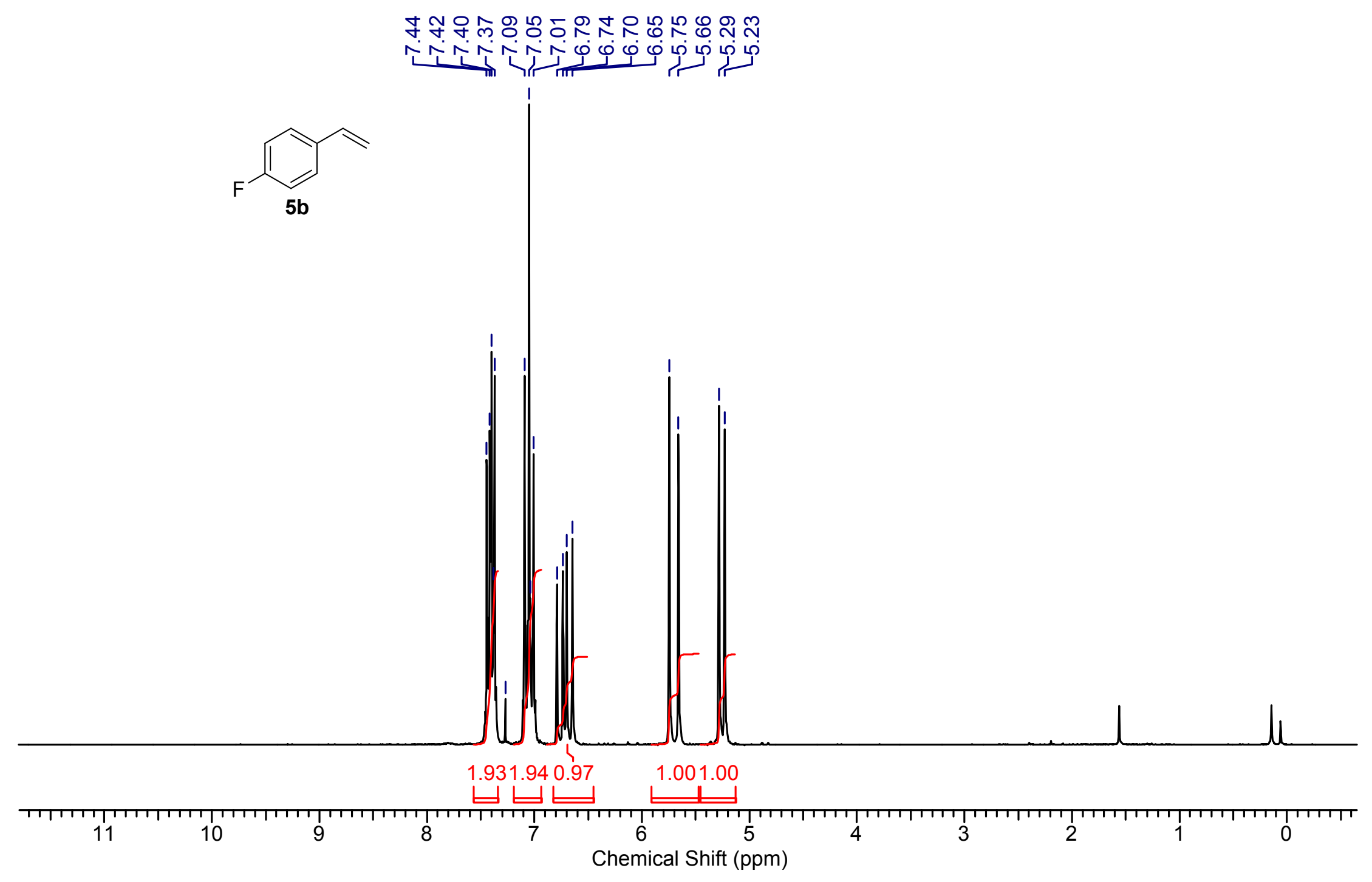

Figure S29. ${ }^{1} \mathrm{H}$ NMR of $\mathbf{5 b}$ 


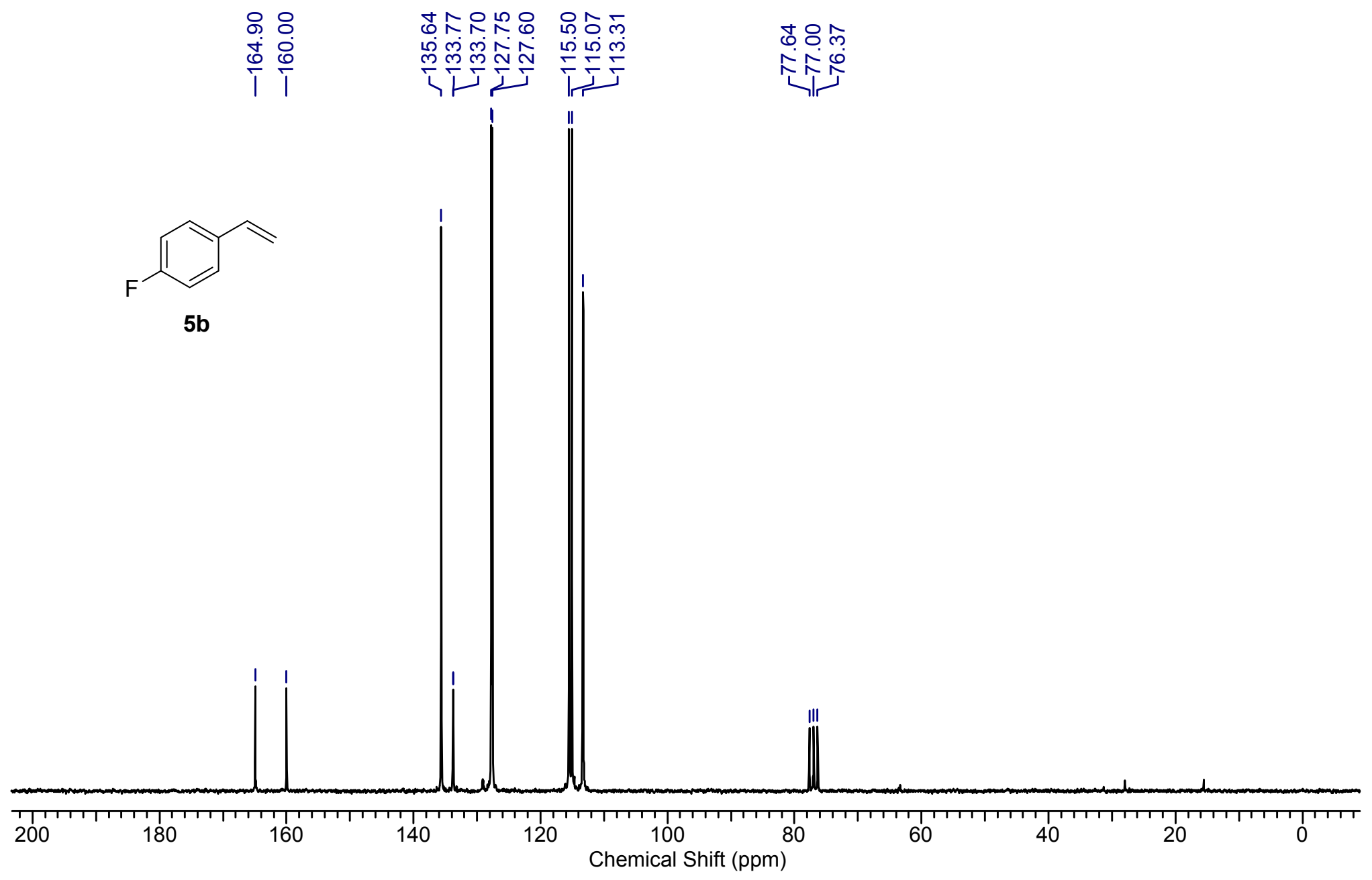

Figure S30. ${ }^{13} \mathrm{C}$ NMR of $\mathbf{5 b}$ 


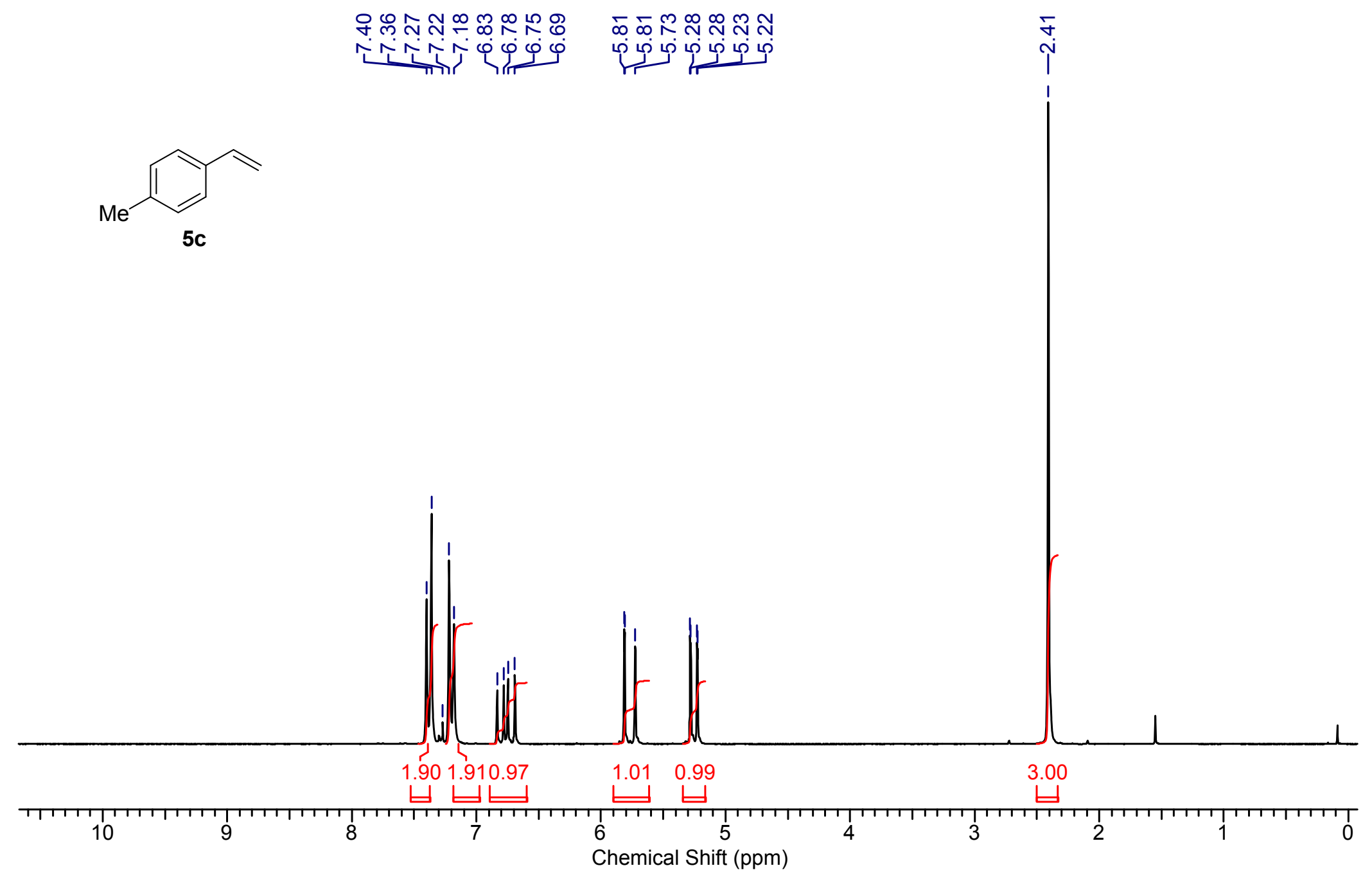

Figure S31. ${ }^{1} \mathrm{H}$ NMR of $\mathbf{5 c}$ 

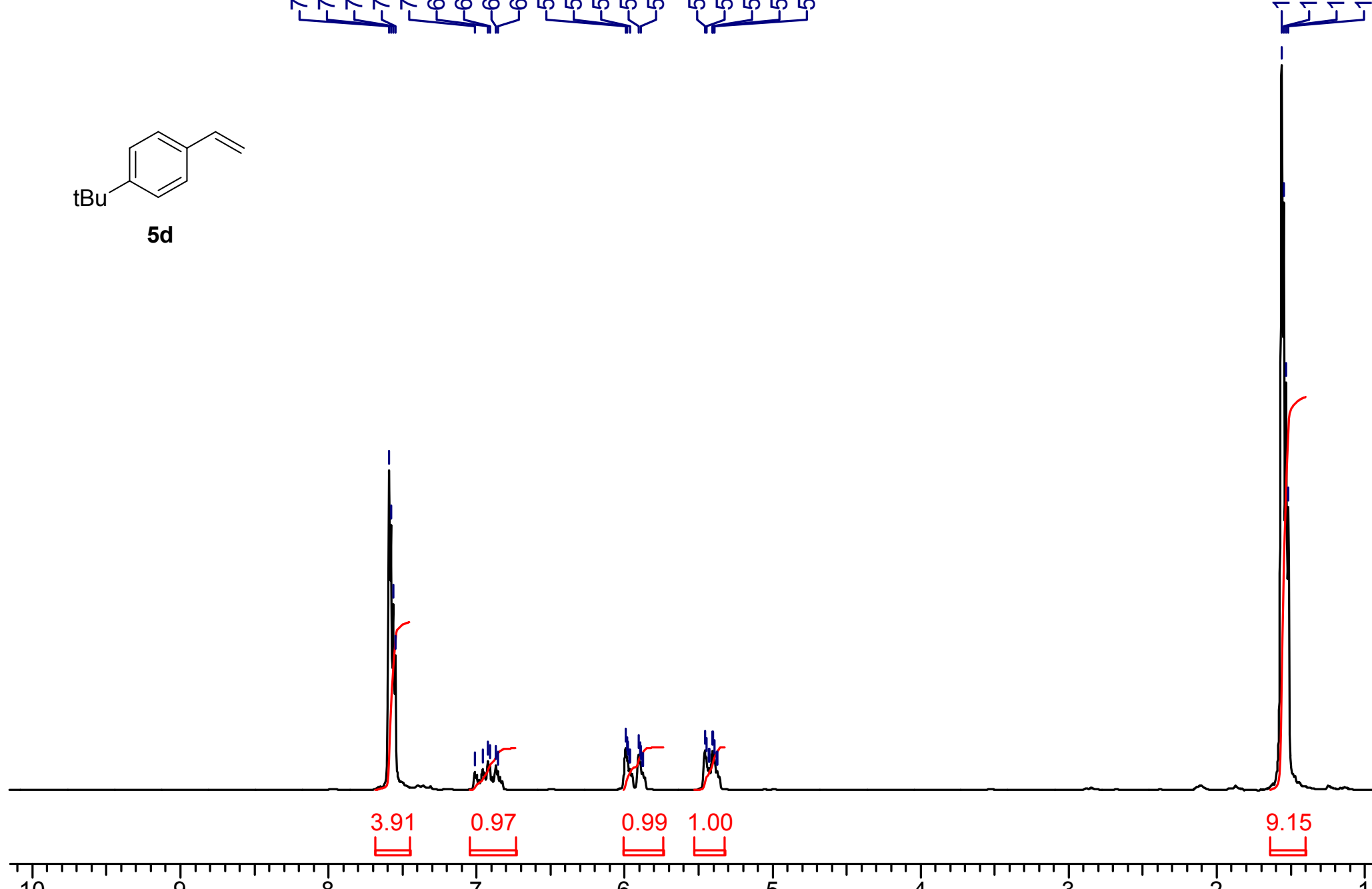

Chemical Shift (ppm)

Figure S32. ${ }^{1} \mathrm{H}$ NMR of $\mathbf{5 d}$ 


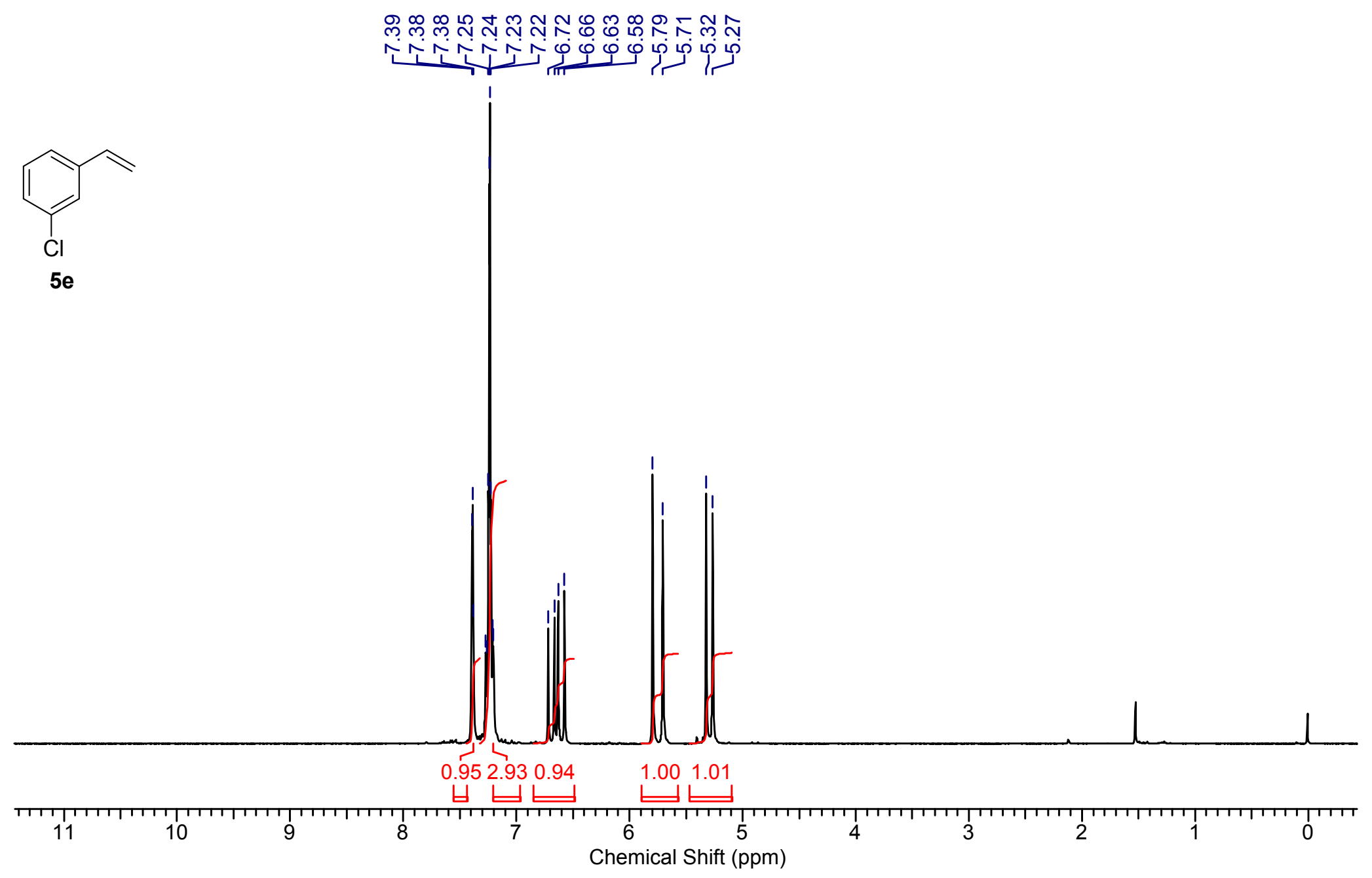

Figure S33. ${ }^{1} \mathrm{H}$ NMR of $5 e$ 